\title{
Kinetic Analysis of the Early Signaling Steps of the Human Chemokine Receptor CXCR4 ${ }^{\text {S }}$
}

\author{
Cristina Perpiñá-Viciano, Ali Işbilir, Aurélien Zarca, Birgit Caspar, Laura E. Kilpatrick, \\ Stephen J. Hill, @Martine J. Smit, Martin J. Lohse, and Carsten Hoffmann
}

Institute of Molecular Cell Biology, Center for Molecular Biomedicine (CMB), University Hospital Jena, University of Jena, Jena, Germany (C.P.-V., C.H.); Institute of Pharmacology and Toxicology, University of Würzburg, Würzburg, Germany (C.P.-V., A.I., M.J.L., C.H.); Max-Delbrück Center for Molecular Medicine, Berlin, Germany (A.I., M.J.L.); Amsterdam Institute for Molecules Medicines and Systems (AIMMS), Division of Medicinal Chemistry, Vrije Universiteit, Amsterdam, The Netherlands (A.Z., M.J.S.); Division of Physiology, Pharmacology and Neuroscience, School of Life Sciences, University of Nottingham, Medical School, Queen's Medical Centre, Nottingham, United Kingdom (B.C., L.E.K., S.J.H.); and Centre of Membrane Proteins and Receptors (COMPARE), University of Birmingham and University of Nottingham, The Midlands, United Kingdom (B.C., L.E.K., S.J.H.)

Received October 7, 2019; accepted May 6, 2020

\section{ABSTRACT}

G protein-coupled receptors (GPCRs) are biologic switches that transduce extracellular stimuli into intracellular responses in the cell. Temporally resolving GPCR transduction pathways is key to understanding how cell signaling occurs. Here, we investigate the kinetics and dynamics of the activation and early signaling steps of the CXC chemokine receptor (CXCR) 4 in response to its natural ligands CXC chemokine ligand (CXCL) 12 and macrophage migration inhibitory factor (MIF), using Förster resonance energy transfer-based approaches. We show that CXCR4 presents a multifaceted response to CXCL12, with receptor activation ( $\approx 0.6$ seconds) followed by a rearrangement in the receptor/G protein complex $(\approx 1$ seconds), a slower dimer rearrangement $(\approx 1.7$ seconds), and prolonged $G$ protein activation ( $\approx 4$ seconds). In comparison, MIF distinctly modulates every step of the transduction pathway, indicating distinct activation mechanisms and reflecting the different pharmacological properties of these two ligands. Our study also indicates that CXCR4 exhibits some degree of ligandindependent activity, a relevant feature for drug development.

\section{SIGNIFICANCE STATEMENT}

The CXC chemokine ligand (CXCL) 12/CXC chemokine receptor (CXCR) 4 axis represents a well-established therapeutic target for cancer treatment. We demonstrate that CXCR4 exhibits a multifaceted response that involves dynamic receptor dimer rearrangements and that is kinetically embedded between receptor-G protein complex rearrangements and $G$ protein activation. The alternative endogenous ligand macrophage migration inhibitory factor behaves opposite to CXCL12 in each assay studied and does not lead to $\mathrm{G}$ protein activation. This detailed understanding of the receptor activation may aid in the development of more specific drugs against this target.

\section{Introduction}

G protein-coupled receptors (GPCRs) transduce signals of diverse nature from the extracellular side into specific responses within the cell through a succession of biochemical events. Generally, binding of an agonist to a receptor causes structural changes in the transmembrane (TM) helices that stabilize the receptor in an active conformation.

This work was supported by the European Union's Horizon 2020 Program under grant agreement 641833 (Oncornet); the Deutsche Forschungsgemeinschaft [Grant TR166 ReceptorLight project C02]; and the Medical Research Council [MR/N020081/1].

https://doi.org/10.1124/mol.119.118448.

S This article has supplemental material available at molpharm. aspetjournals.org.
This is followed by interaction with and subsequent activation of heterotrimeric $G$ proteins, which modulate the activity of different downstream effectors. Receptors can then be phosphorylated by kinases and internalized, resulting in degradation or recycling to the plasma membrane (Hilger et al., 2018).

Crystal structure analysis has provided enormous insights into the molecular mechanisms involved in GPCR activation. However, the detailed temporal dynamics of these changes cannot be resolved in these studies. In this aspect, the use of Förster resonance energy transfer (FRET)-based approaches represents a tool to investigate the dynamics and kinetics of GPCR activation and their downstream signaling events in real time and in intact cells (Lohse et al., 2012). The most

ABBREVIATIONS: AR, adrenergic receptor; BAL, British anti-Lewisite; BSA, bovine serum albumin; CD74, cluster of differentiation 74; CFP, cyan fluorescent protein; $\mathrm{Cl}$, confidence interval; CRE, CAMP-responsive element; CXCL, CXC chemokine ligand; CXCR, CXC chemokine receptor; DPBS, Dulbecco's phosphate-buffered saline; $F_{\mathrm{CFP}}$, CFP fluorescence; FIAsH, fluorescein arsenical hairpin binder; FRET, Förster resonance energy transfer; FSK, forskolin; GPCR, G protein-coupled receptor; HA, hemagglutinin; HEK293, human embryonic kidney cell 293; 5-HT, 5hydroxytryptamine; ICL-3, intracellular loop-3; IQR, interquartile range; Luc, luciferase; mGluR, metabotropic glutamate receptor; MIF, macrophage migration inhibitory factor; NLuc, NanoLuc; PCR, polymerase chain reaction; PEI, polyethylenimine; PTH, parathyroid hormone; PTHR, PTH receptor; TM, transmembrane; wt, wild type; YFP, yellow fluorescent protein. 
common structural characteristic of receptor activation is a large outward shift of the intracellular part of TM domain VI (Altenbach et al., 2008). This unique feature has been the basis for the development of FRET sensors for many receptors, which can report ligand-induced structural rearrangements in a temporal manner (Lohse et al., 2014; Stumpf and Hoffmann, 2016; Wright et al., 2018). These sensors together with other FRET-based approaches have helped to understand the distinct mechanisms of activation between different ligand types (Vilardaga et al., 2005), allosterism (Messerer et al., 2017), and receptor classes (Vilardaga et al., 2003). Most studies have found activation time constants of monomeric GPCRs on the order of 30-50 milliseconds (Hoffmann et al., 2005; Rochais et al., 2007; Reiner et al., 2010; Ziegler et al., 2011). However, there are apparent differences between various receptor types. Thus, activation of class B parathyroid hormone receptor (PTHR) 1 by its large agonist PTH(1-34) is about 20-fold slower (Vilardaga et al., 2003). Another specific case is the activation in dimeric receptors. In a recent study aiming at resolving rapid activation steps of metabotropic glutamate receptors (mGluRs), it was shown that an initial rearrangement of the dimer structure occurs within 1 to 2 milliseconds, whereas conformational changes in the 7-helix TM structure occur within 20 milliseconds (Grushevskyi et al., 2019). Another open question regarding activation in receptor dimers is how the two protomers influence each other. An early study of $\alpha_{2}$-adrenergic/ $\mu$-opioid heterodimers suggested that in such a dimer only one of the two protomers is active (Vilardaga et al., 2008). Likewise, initial studies of mGluRs indicated that only one of the two protomers becomes activated (Hlavackova et al., 2005). However, it now appears clear that activation of both protomers is required for full activation (Kniazeff et al., 2004; Grushevskyi et al., 2019).

The CXC chemokine receptor (CXCR) 4 appears to be a facultative homodimer, and dimer formation may contribute to its signaling function. CXCR4 and its cognate ligand CXCL12, formerly known as stromal cell-derived factor-1, are key players in cell migration in different contexts (Alsayed et al., 2007; Yang et al., 2013). A two-step binding mechanism of chemokines to their chemokine receptors has been proposed (Qin et al., 2015). Binding of CXCL12 preferentially results in activation of $G_{i}$ proteins as well as $\beta$-arrestin recruitment (Heuninck et al., 2019). The CXCR4/CXCL12 axis is an important therapeutic target for the development of new drugs because of its involvement in several types of cancer (Guo et al., 2016; Adlere et al., 2019; Bobkov et al., 2019) in addition to the well-proven role of CXCR4 as a human immunodeficiency virus coreceptor (Tsibris and Kuritzkes, 2007). Recently, macrophage migration inhibitory factor (MIF) has also been demonstrated to bind to CXCR4, but the binding mode and downstream consequences observed greatly differ from those of CXCL12. For instance, MIF binding to the receptor does not result in $\beta$-arrestin recruitment (Bernhagen et al., 2007; Rajasekaran et al., 2016; Lacy et al., 2018). The biomedical importance of CXCR4 and its ligands, their dynamic monomer/dimer equilibrium, the suggested two-step activation mechanism, and the existence of several endogenous agonists with diverse effects all make the spatio-temporal analysis of CXCR4 signaling particularly interesting.

Therefore, we set out to analyze the early steps of CXCR4 activation in response to the two distinct ligands CXCL12 and
MIF. We have combined several FRET approaches to elucidate the temporal aspects of the receptor-mediated early signaling events with subsecond resolution. Our data show that these two ligands modulate the receptor's activity oppositely and that, in the absence of agonist, CXCR4 exhibits some degree of constitutive activity.

\section{Materials and Methods}

\section{Plasmid DNA Constructs}

Human CXCR4 with YFP fused to the $\mathrm{C}$ terminus was a kind gift of F. Bachelerie (INSERM, Université Paris-Sud, France; Levoye et al., 2009). The $\alpha_{2 \mathrm{~A}}$-adrenergic receptor (AR) has been previously described (Bünemann et al., 2003). The $\mathrm{G}$ protein subunits $\mathrm{G} \alpha_{\mathrm{i} 1}, \mathrm{G} \alpha_{\mathrm{i} 1}-\mathrm{cyan}$ fluorescent protein (CFP), G $\beta_{1}, \mathrm{G} \gamma_{2}$, and $\mathrm{G} \gamma_{2}$-CFP and the $\alpha_{2 \mathrm{~A}}$-ARYFP (labeled at the $\mathrm{C}$ terminus) have been previously described (Hein et al., 2005). The $G$ protein sensors for $G_{i 1}, G_{i 2}, G_{i 3}$, and $G_{q}$ have been previously described (Adjobo-Hermans et al., 2011; Van Unen et al., 2016). The cAMP-responsive element (CRE)-Luc construct has been previously described (Watts et al., 2013).

Human CXCR4 and human CXCR4 with three hemagglutinin (HA) tags fused to the $\mathrm{N}$ terminus (3HA-CXCR4) are in pcDEF3 (Vrije Universiteit, Amsterdam, The Netherlands). The 3HA-CXCR4 construct was employed to label the receptor with enhanced CFP (BD Biosciences). For that, the fluorescent protein was fused in-frame to the $\mathrm{C}$ terminus of CXCR4 by standard PCR extension overlap technique. The C-terminal stop codon of the receptor and the initial methionine codon of the fluorescent protein were deleted. The resulting construct was named CXCR4-CFP and contained the fluorescent protein after S352. To create the different receptor sensors, the fluorescein arsenical hairpin binder (FlAsH)-binding motif CCPGCC was inserted at different positions within the intracellular loop-3 (ICL-3) of the receptor in the CXCR4-CFP construct: between amino acids L226 and S227 (CXCR4-FlAsH226-CFP), between amino acids H228 and S229 (CXCR4-FlAsH228-CFP), or between amino acids S229 and K230 (CXCR4-FlAsH229-CFP). Cloning was performed using site-directed mutagenesis by overlap extension PCR. To create analogous constructs only containing the FlAsHbinding motif in different positions of ICL-3 (CXCR4-FlAsH226, CXCR4-FlAsH228, and CXCR4-FlAsH229), the CFP was removed from the $\mathrm{C}$ terminus of the corresponding receptor sensors via standard PCR.

The Pfu polymerase was used for amplifying DNA in the PCRs, and the T4 ligase enzyme was used for ligation. Escherichia coli DH5 $\alpha$ (Invitrogen) was used as a host to clone all the genes described. All constructs were verified by sequencing (Eurofins Genomix GmbH, Germany).

\section{Ligands}

Recombinant human CXCL12 was purchased from Peprotech (30028A); recombinant human MIF was purchased from Peprotech (30069); norepinephrine was purchased from Sigma Aldrich (A9512); and IT1t was purchased from Tocris (4596). AMD3100 was purchased from Sigma Aldrich (A5602), and CXCL12-AlexaFluor647 was from Almac (CAF-11).

\section{Cell Lines and Cell Culture}

Human embryonic kidney cell 293 (HEK293) and HEK293T cell lines (American Type Culture Collection) (CRL-1573 and CRL-3216) were cultured using Dulbecco's modified Eagle's medium supplemented with $4.5 \mathrm{~g} / \mathrm{l}$ glucose (Gibco), 10\% (v/v) FBS (Biochrom), $1 \%$ penicillin/streptomycin (Gibco), and 1\% L-glutamine (PanBiotech). Cells were kept in a humidified $7 \% \mathrm{CO}_{2}$ atmosphere at $37^{\circ} \mathrm{C}$. For routine maintenance, cells were split every 2 or 3 days by rinsing them with Dulbecco's phosphate-buffered saline (DPBS) (Gibco) and then 
trypsin-EDTA (PanBiotech). Cell lines were routinely tested for mycoplasma contamination by PCR using a primer set specific for the highly conserved $16 \mathrm{~S}$ ribosomal RNA-coding region in the mycoplasma genome. Cells have not been authenticated.

The N-terminal NanoLuc (NLuc)-labeled CXCR4 receptor construct was created from a previously described construct (Stoddart et al., 2015) and was used for the binding competition assay. Briefly, the adenosine $A_{1}$ receptor cDNA was replaced with that encoding the human CXCR4 (NM_003467.2). The resultant construct fused NLuc in-frame with the membrane signal sequence from the $5-\mathrm{HT}_{3 \mathrm{~A}}$ receptor within pcDNA3.1 to generate signal-NLuc. The human CXCR4 sequence (methionine start signal removed) was then fused to the $3^{\prime}$ end of signal-NLuc via a short Gly-Ser linker. Stable mixedexpression populations of HEK293G cell lines [HEK293 expressing the GloSensor (20F) cAMP biosensor; Promega Corporation] expressing the NLuc-CXCR4 cDNA construct were created by transfecting cells with FuGENE HD (Promega Corporation) following the manufacturer's instructions. Cells were then subject to antibiotic selection using G418 disulfate salt ( $1 \mathrm{mg} / \mathrm{ml}$; Sigma Aldrich) for 2 to 3 weeks, screened for luminescence expression, and expanded. The HEK293G-NLuc-CXCR4 cell line was cultured using Dulbecco's modified Eagle's medium (Sigma Aldrich) supplemented with $10 \%$ FBS (Sigma Aldrich). Cells were kept in a humidified $5 \% \mathrm{CO}_{2}$ atmosphere at $37^{\circ} \mathrm{C}$. For routine maintenance, cells were split every 2 or 3 days by using DPBS (Lonza) and trypsin-EDTA $(0.25 \% \mathrm{w} / \mathrm{v}$ versene; Lonza).

\section{FIAsH Labeling}

FlAsH labeling was done as previously described (Hoffmann et al., 2010) right before the measurements. In brief, transfected cells grown on 24-mm glass coverslips (Hartenstein, Würzburg, Germany) or 40-mm WillCo dishes (WillCo Wells) were washed twice with labeling buffer (150 mM NaCl, $10 \mathrm{mM}$ HEPES, $2.5 \mathrm{mM} \mathrm{KCl}, 4 \mathrm{mM} \mathrm{CaCl}_{2}, 2 \mathrm{mM}$ $\mathrm{MgCl}_{2}$ freshly supplemented with $1.8 \mathrm{~g} / \mathrm{l}$ glucose; $\mathrm{pH}$ 7.3). Subsequently, cells were incubated for 1 hour at $37^{\circ} \mathrm{C}$ with labeling buffer containing $1 \mu \mathrm{M}$ FlAsH (commercially available from Thermo Fisher Scientific, Darmstadt, Germany as TC-FlAsH labeling kit) and $12.5 \mu \mathrm{M}$ 1,2-ethanedithiol (Sigma Aldrich). Cells were rinsed twice and incubated for 10 minutes at $37^{\circ} \mathrm{C}$ in labeling buffer containing $250 \mu \mathrm{M}$ 1,2-ethanedithiol to reduce nonspecific FlAsH labeling. Finally, cells were washed twice and kept in media at $37^{\circ} \mathrm{C}$ until measurement.

\section{Confocal Microscopy}

HEK293 cells were seeded on 24-mm glass coverslips, which had been previously coated with poly-D-lysine ( $1 \mathrm{mg} / \mathrm{ml}$; MP Biomedicals) for 30 minutes and washed once with DPBS, and placed in wells of a six-well plate. After 6 hours, and for each well, cells were transfected with $0.5 \mu \mathrm{g}$ of the different CXCR4 sensors (CXCR4-FlAsH226-CFP, CXCR4-FlAsH228-CFP, or CXCR4-FlAsH229-CFP) using Effectene (Qiagen), following the manufacturer's instructions. Prior to transfection, the media of the cells was exchanged for fresh media. Cells were analyzed 48 hours after transfection. When indicated, cells were FlAsH-labeled right before the measurement. During the experiment, cells were kept in imaging buffer (140 mM NaCl, $5.4 \mathrm{mM} \mathrm{KCl,} 2 \mathrm{mM}$ $\mathrm{CaCl}_{2}, 1 \mathrm{mM} \mathrm{MgCl} 2,10 \mathrm{mM}$ HEPES; $\mathrm{pH}$ 7.3).

Confocal microscopy was performed using a Leica TCS SP8 system (Leica Microsystems, Germany) with an Attofluor holder (Molecular Probes), and images were taken with a $63 \times$ water objective (numerical aperture 1.4). CFP was excited with a diode laser line at $442 \mathrm{~nm}$, and fluorescence intensities were recorded from 470 to $550 \mathrm{~nm}$. FlAsH was excited with an argon laser line at $514 \mathrm{~nm}$, and fluorescence intensities were recorded from 525 to $600 \mathrm{~nm}$. Images were acquired at $1024 \times 1024$-pixel format, line average 3 and $400 \mathrm{~Hz}$. To avoid bleed through, parallel images of CFP and FlAsH were taken in sequential scan. Images were analyzed using the Leica Application Suite Advanced Fluorescence Software (Leica Microsystems).

\section{Single-Cell FRET Experiments}

Microscopic FRET Set-Up. FRET measurements were performed on an inverted microscope (Zeiss Axiovert 200; Zeiss) equipped with an oil immersion $63 \times$ objective lens and a dualemission photometric system (Till Photonics). The transfected cells were excited with light from a polychrome IV (Till Photonics) at a frequency of $10 \mathrm{~Hz}$ with 40 milliseconds illumination out of a total time of 100 milliseconds. Emission of the donor (CFP or mTurquoise 2; $480 \pm 20 \mathrm{~nm}$ ) and acceptor (YFP, FlAsH, or Venus; $535 \pm$ $15 \mathrm{~nm}$ ) and the FRET ratio (Facceptor/Fdonor) were monitored simultaneously (beam splitter DCLP $505 \mathrm{~nm}$ ) upon excitation at $436 \pm 10 \mathrm{~nm}$ (beam splitter DCLP $460 \mathrm{~nm}$ ). Fluorescence signals were detected by photodiodes, digitalized using an analog-digital converter (Digidata 1440A; Axon Instruments), and stored with Clampex 9.0 software (Molecular Devices, Sunnyvale, CA).

Determination of FRET Efficiency. Determination of the FRET efficiency was performed as previously described (Jost et al., 2008). HEK293 cells were prepared in $24-\mathrm{mm}$ glass coverslips, as described for confocal microscopy. To study the basal intramolecular FRET, cells were transfected with $0.5 \mu \mathrm{g}$ of CXCR4-FlAsH226-CFP, CXCR4-FlAsH228-CFP, or CXCR4-FlAsH229-CFP sensor per well. To study the basal intermolecular FRET, cells were transfected with 0.3 $\mu \mathrm{g}$ of CXCR4-CFP and $0.3 \mu \mathrm{g}$ of CXCR4-FlAsH228 per well. Transfection was performed using Effectene. Prior to the measurement, cells were FlAsH-labeled. Then, the coverslips were mounted on an Attofluor holder and kept in $999 \mu \mathrm{l}$ of imaging buffer. During the measurement (after approximately 30 seconds of recording), $1 \mu l$ of British anti-Lewisite (BAL) (Fluka) was added to yield a final BAL concentration of $5 \mathrm{mM}$, which displaced FlAsH from its binding site in the receptors' ICL-3. The FRET efficiency was calculated by analyzing the increase in the CFP emission [CFP fluorescence $\left.\left(\mathrm{F}_{\mathrm{CFP}}\right)\right]$ due to dequenching using the formula $\left(\mathrm{F}_{\mathrm{CFP}, \max }-\mathrm{F}_{\mathrm{CFP} \text {,min }}\right) / \mathrm{F}_{\mathrm{CFP} \text {,max }}$ and the Clampfit software (Molecular Devices). Data are shown as a scatter plot with mean and S.D., in which each dot represents an individual cell. At least three independent repeats were performed for each condition. Measurements were performed using the microscopic FRET set-up described above.

Kinetic Measurements. For kinetic experiments, HEK293 cells were seeded on 40-mm WillCo dishes previously coated with polyD-lysine for 30 minutes and washed once with DPBS. Six hours later, cells were transfected with the appropriate construct(s) using Effectene. For measuring receptor activation, $0.7 \mu \mathrm{g}$ of each sensor (CXCR4-FlAsH226-CFP, CXCR4-FlAsH228-CFP, or CXCR4-FlAsH229CFP) were transfected per dish, and FlAsH labeling was performed before the measurement. For receptor/G protein interaction studies, $0.6 \mu \mathrm{g}$ of CXCR4-YFP, $0.7 \mu \mathrm{g}$ of $\mathrm{G} \alpha_{\mathrm{i} 1}, 0.3 \mu \mathrm{g}$ of $\mathrm{G} \beta_{1}$, and $0.2 \mu \mathrm{g}$ of $\mathrm{G} \gamma_{2^{-}}$ CFP were transfected per dish. When indicated, $0.6 \mu \mathrm{g}$ of CXCR4YFP, $0.7 \mu \mathrm{g}$ of $\mathrm{G} \alpha_{\mathrm{i} 1}$-CFP, $0.3 \mu \mathrm{g}$ of $\mathrm{G} \beta_{1}$, and $0.2 \mu \mathrm{g}$ of $\mathrm{G} \gamma_{2}$ were transfected instead. For measuring $\mathrm{G}$ protein activation, $0.4 \mu \mathrm{g}$ of receptor (CXCR4 or $\alpha_{2 \mathrm{~A}}$-AR) or empty plasmid and $0.75 \mu \mathrm{g}$ of $\mathrm{G}$ protein sensor $\left(G_{i 1}, G_{i 2}\right.$ or $\left.G_{i 3}\right)$ were transfected per dish. For measuring rearrangements within dimers, $0.5 \mu \mathrm{g}$ of CXCR4-CFP and $0.5 \mu \mathrm{g}$ of CXCR4-YFP were transfected per dish. Prior to transfection, the media of the cells was exchanged for fresh media. FRET measurements were performed 48 hours after transfection using the microscopic FRET set-up.

During the experiments, cells were kept in imaging buffer. Then, using the BioPen microfluidic system (Fluicell, Gothenburg, Sweden; Ainla et al., 2010, 2012; Wright et al., 2018), single cells were exposed to the different solutions, as follows: cells were initially washed (approximately for 10-20 seconds) with imaging buffer to establish a baseline. Then, cells were stimulated with buffer supplemented with the appropriate ligand (CXCL12, MIF, or norepinephrine) at the indicated concentrations in the figures, until the response reached a plateau. Then, cells were washed again with imaging buffer, ideally, until reversal of the ligand-induced signal was observed (return to baseline). When indicated, a second stimulation and wash-out were 
performed. The duration of the stimuli is indicated in the figures as horizontal black lines. All the solutions contained $0.1 \%$ bovine serum albumin (BSA) (AppliChem).

For determining the kinetics of each process ( $\tau$ values; apparent onor off-rate), the FRET ratio of individual experiments was fitted to a one-component exponential decay function using the Clampfit software. For each case, $\tau$ values are shown as a scatter plot with median and interquartile range (IQR), in which $N$ is the total number of individual cells measured in several independent experiments, as indicated in the figure legends. When required, statistical significance was tested using Mann-Whitney test or Kruskal-Wallis test. For determining the amplitude of the signals, maximum and minimum values were considered, and data are reported as mean \pm S.E.M.

The emission of the acceptor fluorophores was corrected for that attributable to bleed through (spillover of donor into the 535-nm channel) and direct excitation (acceptor emission at $436 \mathrm{~nm}$ excitation). FRET was normalized and corrected for photobleaching. Processing of the data were done with OriginPro 2016 (OriginLab Corporation, Northampton, MA).

Acceptor Photobleaching Experiments. HEK293 cells were prepared in 24-mm glass coverslips as previously described for confocal microscopy. Six hours later, cells were transfected with 0.6 $\mu \mathrm{g}$ of CXCR4-YFP or $\alpha_{2 \mathrm{~A}}$-AR-YFP, $0.7 \mu \mathrm{g}$ of $\mathrm{G}_{\mathrm{i} 1}, 0.3 \mu \mathrm{g}$ of $\mathrm{G} \beta_{1}$, and 0.2 $\mu \mathrm{g}$ of $\mathrm{G} \gamma_{2}-\mathrm{CFP}$, per dish, using Effectene. Prior to transfection, the media of the cells was exchanged for fresh media. FRET measurements were performed 48 hours after transfection using the microscopic FRET set-up. For the experiment, CFP and YFP fluorescence intensities were measured at $10 \mathrm{~Hz}$ for 40 seconds with 20 milliseconds illumination out of a total time of 100 milliseconds. Then, the donor was photobleached by illuminating for 9 minutes at $490 \mathrm{~nm}$ with 90 milliseconds illumination out of a total time of 100 milliseconds. Subsequently, the CFP and YFP fluorescence intensities were measured again for 40 seconds with 20 milliseconds illumination out of a total time of 100 milliseconds. During the measurements, cells were kept in $600 \mu \mathrm{l}$ of imaging buffer. When indicated, cells expressing CXCR4 and the G protein subunits were pretreated with media containing $10 \mu \mathrm{M}$ IT1t for 4 hours and kept in $600 \mu$ limaging buffer containing $10 \mu \mathrm{M}$ IT1t during the measurement. The change in the $\mathrm{F}_{\mathrm{CFP}}$ was calculated by considering the values of CFP fluorescence right before and after the bleaching process, using the formula $\left[\left(\mathrm{F}_{\mathrm{CFP} \text {,after }}-\mathrm{F}_{\mathrm{CFP} \text {,before }}\right) / \mathrm{F}_{\mathrm{CFP} \text {,after }}\right]$ and the Clampfit software. For each condition, three independent repeats were performed. Data are shown as a box plot in which the whiskers represent maximum and minimum values. Statistical significance between groups was tested using unpaired $t$ test.

\section{CRE-Luc Reporter-Gene Assay}

The signaling properties of the different CXCR4 constructs were characterized using a CRE-driven reporter-gene assay. HEK293T cells were transfected with the CXCR4 constructs (CXCR4, CXCR4-CFP, or CXCR4-FlAsH228-CFP) and the CRE-Luc construct using 25-kDa linear polyethylenimine (PEI) (Polysciences) as DNA carrier agent in a 1:10 ratio (DNA/PEI). For transfection, $2 \mu \mathrm{g}$ of DNA were combined with $12 \mu \mathrm{g}$ of PEI in a total volume of $250 \mu \mathrm{l} 150 \mathrm{mM} \mathrm{NaCl}$ and incubated for 20 minutes at room temperature. Then, 1 million resuspended cells were added to the DNA/PEI mix, and $80 \mu \mathrm{l}$ were seeded at a density of 32,000 cells/well in a white, flat-bottom 96 -well plate (Greiner Bio One). Analysis was done 24 hours after seeding the cells using Mithras LB940 (Berthold Technologies).

The day of the measurement, cells were incubated in media or media supplemented with $1 \mu \mathrm{M}$ forskolin (FSK) (LC Laboratories) and increasing concentrations of CXCL12 (as indicated in the figure) and incubated for 6 hours at $37^{\circ} \mathrm{C}$. Subsequently, the media was substituted for $25 \mu \mathrm{l}$ of luciferase assay reagent $\left[45 \mathrm{mM}\right.$ Tris $\mathrm{H}_{3} \mathrm{PO}_{4} \mathrm{pH} 7.8$, $45 \%$ glycerol, 3\% Triton X-100, $1 \mathrm{mM}$ DTT, $20 \mathrm{mM} \mathrm{MgCl}_{2}, 800 \mu \mathrm{M}$ D-Luciferin (Duchefa), $80 \mu \mathrm{M}$ ATP] and incubated 20 minutes in the dark. Finally, the plate luminescence was measured and quantified.
The data from concentration-response curves were fitted to a threeparameter sigmoidal model using GraphPad. For each construct tested, four independent experiments were performed in quadruplicate. Means of $\mathrm{EC}_{50}$ values and asymmetric $95 \%$ confidence interval (CI) are reported in the text and have been calculated based on the logarithmic values $\left(\log \mathrm{EC}_{50}\right)$.

\section{Binding Competition Assay}

Twenty-four hours prior to assay, HEK293G cells stably expressing NLuc-CXCR4 were seeded on poly-D-lysine-coated white flat-bottom 96 -well plates at a density of 40,000 cells/well. On the day of the assay, plating medium was removed and replaced with Hanks' balanced salt solution $/ 0.1 \%$ protease-free BSA (Hanks' balanced salt solution composition $10 \mathrm{mM}$ HEPES, $146 \mathrm{mM} \mathrm{NaCl}, 5 \mathrm{mM} \mathrm{KCl}, 1 \mathrm{mM}$ $\mathrm{MgSO}_{4}, 2 \mathrm{mM}$ sodium pyruvate, $1.3 \mathrm{mM} \mathrm{CaCl}_{2}$, and $1.5 \mathrm{mM} \mathrm{NaHCO}_{3}$; $\mathrm{pH} 7.4$ with the addition of $10 \mathrm{mM}$ glucose after autoclaving). A fixed concentration of the fluorescent ligand CXCL12-AlexaFluor647 $(10 \mathrm{nM})$ was added simultaneously in triplicate wells, alongside increasing concentrations of unlabeled CXCL12, AMD3100, or MIF for 120 minutes at $37^{\circ} \mathrm{C}$. The NLuc substrate was then added $(50 \times$ dilution), and plates were left to equilibrate in the dark for 5 minutes.

Sequential dual luminescence and fluorescence readings were recorded using a PHERAstar FS plate reader (BMG Labtech, Germany) with $460 \mathrm{~nm}$ (80-nm bandpass; donor NLuc emission) and $>610 \mathrm{~nm}$ longpass filters (acceptor CXCL12-AF647 emission). Raw bioluminescence resonance energy transfer ratios were calculated from the ratio of acceptor to donor emission values. Data were fitted to a three-parameter sigmoidal model using GraphPad. Data were pooled from five-sixths independent experiments (six independent experiments with CXCL12 and MIF ligands, of which five experiments also used AMD3100) and are expressed as mean \pm S.E.M.

\section{G Protein Activation in 96-Well Plates}

HEK293T cells were seeded in 100-mm plates and grown until they reached $60 \%-65 \%$ confluency. Then, cells were transfected with $1.5 \mu \mathrm{g}$ of receptor (CXCR4, CXCR4-FlAsH226, CXCR4-FlAsH228, or CXCR4-FlAsH229) and $3 \mu \mathrm{g}$ of FRET-based $\mathrm{G}$ protein sensor $\left(\mathrm{G}_{\mathrm{i} 1 \text {, }}\right.$ $\mathrm{G}_{\mathrm{i} 2}, \mathrm{G}_{\mathrm{i} 3}$, or $\mathrm{G}_{\mathrm{q}}$ ) plasmid using Effectene. When indicated, empty plasmid was transfected instead of receptor. Prior to transfection, the media of the cells were replaced by fresh media. Twenty-four hours after transfection, cells were harvested in culture media and seeded at a density of 30,000 cells/well in black flat-bottom 96 -well plates (Brand). The plates had been preincubated with poly-D-lysine $(1 \mathrm{mg} / \mathrm{ml})$ for 30 minutes and washed once with DPBS. Analysis was done 24 hours after seeding the cells.

To generate concentration-response curves in a microplate reader, cells were incubated at $37^{\circ} \mathrm{C}$ over 30 minutes with $90 \mu$ l of imaging buffer containing $0.1 \%$ BSA. Afterward, the fluorescence was read for 5 minutes to determine the preread signal. After the reading, $10 \mu \mathrm{l}$ of buffer or increasing concentrations of CXCL12 (indicated in the figure) were added to the wells for a total assay volume of $100 \mu$ l. Fluorescence was read again for 20 minutes to determine the postread signal. During the measurement, cells were kept at $37^{\circ} \mathrm{C}$. CXCL12 was prepared in imaging buffer containing $0.1 \%$ BSA. The FRET change produced by each concentration of ligand tested was corrected for the signal obtained in vehicle (nonligand; buffer)-treated cells. To determine the $\mathrm{EC}_{50}$ values for $\mathrm{G}$ protein activation, data were fitted to a three-parameter sigmoidal model using GraphPad. $N=5$ independent experiments performed in quadruplicate. Means of $\mathrm{EC}_{50}$ values and asymmetric 95\% CI are reported in the text and have been calculated based on the logarithmic values $\left(\log \mathrm{EC}_{50}\right)$. Statistical significance was tested using one-way ANOVA followed by Tukey's test on the $\log \mathrm{EC}_{50}$ values.

To investigate basal G protein activity, HEK293T cells transfected with CXCR4 and the $\mathrm{G}_{\mathrm{i} 2}$ sensor were seeded at a density of 15,000 cells/well after the same protocol as described above for concentration-response curves. Three different conditions were 
analyzed in parallel: 1) buffer, 2) IT1t treatment, and 3) CXCL12 treatment. For 1), cells were incubated with $100 \mu \mathrm{l}$ of imaging buffer for 4 hours. For 2), cells were incubated with $100 \mu$ l of imaging buffer supplemented with $100 \mu \mathrm{M}$ IT1t for 4 hours. For 3), cells were incubated with $90 \mu \mathrm{l}$ of imaging buffer for 4 hours, and 2 minutes before the measurement, $10 \mu \mathrm{l}$ of $1 \mu \mathrm{M}$ CXCL12 were added (final CXCL12 concentration: $100 \mathrm{nM}$ ). All the solutions contained $0.1 \%$ BSA. After the treatments, fluorescence was read for 8 minutes. The FRET detected under the three different conditions was normalized to "buffer treatment," which was set to 100. Three independent repeats were performed in quadruplicate. Data are shown as a bar graph with S.D. Statistical significance between groups was tested using unpaired $t$ test.

Experiments were performed using Synergy Neo2 Multi-Mode Microplate Reader (Biotek) with Gen5 Data Analysis Software. During the measurements, cells were excited at $420 / 50 \mathrm{~nm}$ (Biotek CFP-YFP Filter; 1035013), and emission was monitored at 485/20 and 540/25 nm (Biotek CFP-YFP Filter; 1035043).

\section{Quantification and Statistical Analysis}

Statistical analyses were performed using GraphPad Prism software (version 7). The statistical tests applied can be found in the figure legends and Materials and Methods section. When normal distribution could be assumed, $t$ test or ANOVA followed by Tukey's test was performed. When normal distribution could not be assumed, MannWhitney test or Kruskal-Wallis test was performed. The minimum criterion for statistical significance was $P * 0.05$. It should be noted that because of the exploratory nature of our research, the $P$ values reported are descriptive and should not be interpreted as hypothesis testing.

\section{Results}

Development and Functional Characterization of FRET-Based CXCR4 Sensors. To study the conformational movements that CXCR4 undergoes during ligandinduced activation, we generated three different FRET sensors for CXCR4 with modifications in different positions. Addition of FRET-compatible fluorescent proteins or tags into the $\mathrm{C}$ terminus and intracellular loops has been established before in several GPCRs to investigate their activation (Stumpf and Hoffmann, 2016). Conformational changes induced upon ligand binding alter the distance and/or orientation between the fluorophores, resulting in changes in FRET that can be monitored in real time (Fig. 1A). Therefore, a CFP was fused to the C-terminal end of CXCR4, and the short FlAsH-binding motif CCPGCC was inserted in three different positions within the ICL-3: between L226 and S227 to generate the CXCR4-FlAsH226-CFP sensor, between H228 and S229 to generate the CXCR4-FlAsH228-CFP sensor, or between S229 and K230 to generate the CXCR4-FlAsH229CFP sensor. The receptor constructs were characterized for correct functional properties. In particular, the CXCR4FlAsH228-CFP sensor was chosen for full characterization, since it produced the highest FRET change upon agonist binding, as shown in the following section. Analysis by confocal microscopy showed that all three CXCR4 sensors localized to the plasma membrane (Fig. 1B upper panel and Supplemental Fig. 1A). Along with this, we observed that FlAsH specifically binds to the FlAsH-binding motif in ICL-3 (Fig. 1B lower panel), as previously reported for analogous receptor sensors (Hoffmann et al., 2005, 2010).

To investigate intramolecular FRET in the sensors, we performed acceptor-bleaching experiments using BAL (2,3dimercapto-1-propanol) in cells transfected with the sensors and FlAsH-labeled prior to the measurement. BAL displays very high affinity for arsenicals and, at high concentrations, displaces FlAsH from its binding site. Addition of $5 \mathrm{mM} \mathrm{BAL}$ led to a decrease in the FlAsH signal and dequenched CFP, proving the existence of basal intramolecular FRET (Supplemental Fig. 2A). FRET efficiency was calculated based on the increase in the CFP emission and was determined to be $12.0 \% \pm 3.0 \%$ (mean \pm S.D.) for the CXCR4-FlAsH228-CFP sensor (Fig. 1C). The constructs CXCR4-FlAsH226-CFP and CXCR4-FlAsH229-CFP showed FRET efficiencies of $5.0 \% \pm 2.7 \%$ and $16.5 \% \pm 4.3 \%$, respectively (Supplemental Fig. 1B). No basal intermolecular FRET was detected in cells coexpressing CXCR4-CFP and CXCR4-FlAsH228 (Supplemental Fig. 2B), which indicates that the observed signal results from intramolecular FRET and not from crosstalk between adjacent receptors or between protomers of a dimer.

We then characterized the constructs for their ability to induce G protein signaling in response to CXCL12, since they contain the FlAsH-binding sequence in ICL-3, a region generally known to be important for $\mathrm{G}$ protein interaction $(\mathrm{Hu}$ et al., 2010; Chung, 2013). For this purpose, we used a FRETbased $G_{i 1}$ sensor that measures $G$ protein activation as a change in FRET between the labeled $\mathrm{G} \alpha$ and $\mathrm{G} \gamma$ subunits (van Unen et al., 2016). HEK293 cells cotransfected with the $\mathrm{G}_{\mathrm{i} 1}$ sensor and either CXCR4 or CXCR4-FlAsH228 were stimulated with increasing concentrations of CXCL12 in a 96-well plate assay format. Results showed that CXCR4FlAsH228 preserves the ability to activate $\mathrm{G}_{\mathrm{i} 1}\left(\mathrm{EC}_{50}=15.5\right.$ [9.3-25.9] nM; mean and asymmetric 95\% CI) although with lower potency than the wild-type $(\mathrm{wt})$ receptor $\left(\mathrm{EC}_{50}=3.4\right.$ [2.3-4.9] nM; Fig. 1D). The CXCR4-FlAsH226 and CXCR4FlAsH229 constructs also activated $\mathrm{G}_{\mathrm{i} 1}$ with very similar potencies to CXCR4-FlAsH228 $\left(\mathrm{EC}_{50}=18.1\right.$ [5.3-62.2] and 17.1 [4.9-59.3] nM, respectively; Supplemental Fig. 1C). Subsequently, and to examine the functionality of the complete sensor, we assessed the capacity of CXCL12 to inhibit FSKinduced cAMP accumulation in cells expressing CXCR4FlAsH228-CFP in comparison with cells expressing CXCR4-CFP or the wt receptor. The results showed that cells expressing the sensor exhibited lower potency for the inhibition of FSK-induced cAMP production $\left(\mathrm{EC}_{50}=19.0\right.$ [3.5-102.7] $\left.\mathrm{nM}\right)$ in comparison with the wt $\left(\mathrm{EC}_{50}=2.2[0.6-8.0] \mathrm{nM}\right)$. We also noted that the presence of CFP at the end of the $\mathrm{C}$ terminus contributes to an intermediate potency of the sensor with regards to $G_{i}$ signaling $\left(\mathrm{EC}_{50}=10.6\right.$ [1.9-57.9] nM) (Fig. 1E). Most importantly, the maximal activity of the sensor was comparable to the wt receptor. On the basis of this validation, these three constructs can serve as sensors to monitor ligand-induced intramolecular conformational changes.

The FRET-Based CXCR4 Sensors Report the Dynamics and Kinetics of Receptor Activation and Deactivation. The CXCR4 sensors were used for further FRET experiments in single cells. To investigate the conformational changes upon receptor activation, HEK293 cells transiently expressing the receptor sensors and FlAsH-labeled prior to the measurements were stimulated with $30 \mu \mathrm{M}$ CXCL12. A saturating concentration of ligand is required to determine the maximal and fastest kinetics of the process as well as to ensure that ligand diffusion to receptors is not time-limiting. A BioPen microfluidic device (Fluicell) was employed for delivering the solutions. This perfusion system allows the precise 
A

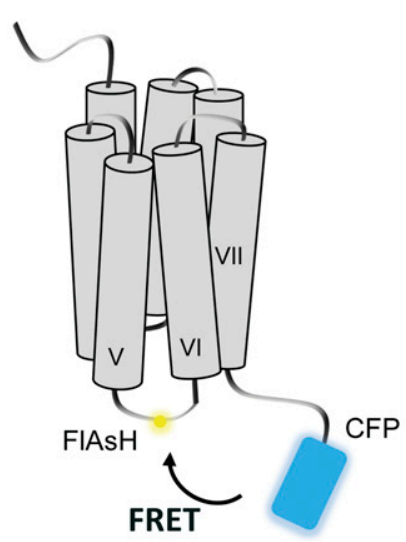

B

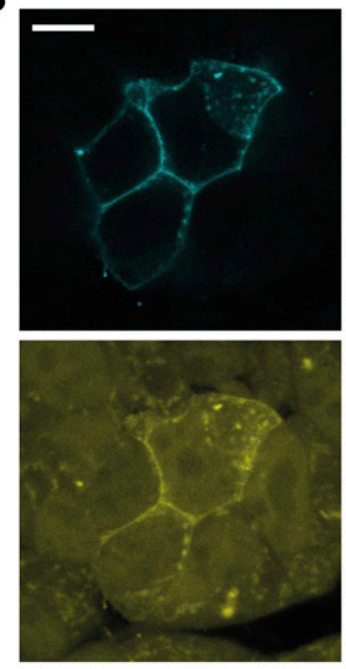

C

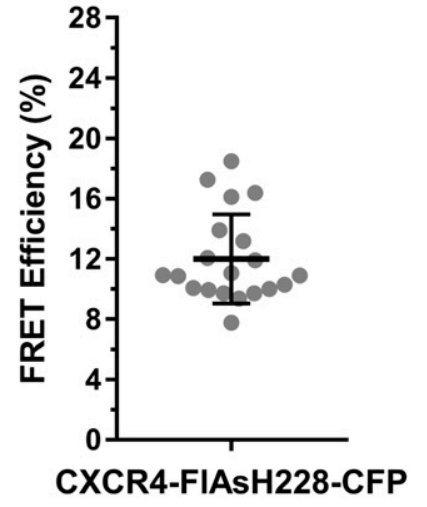

D

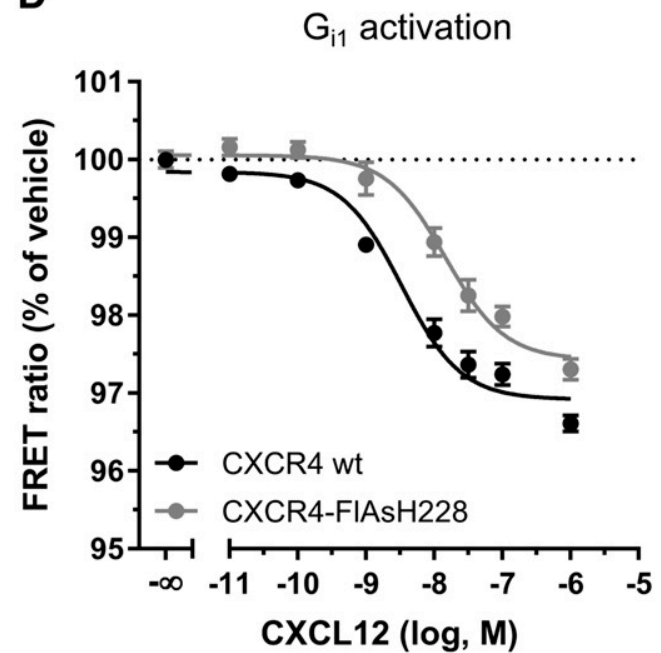

E
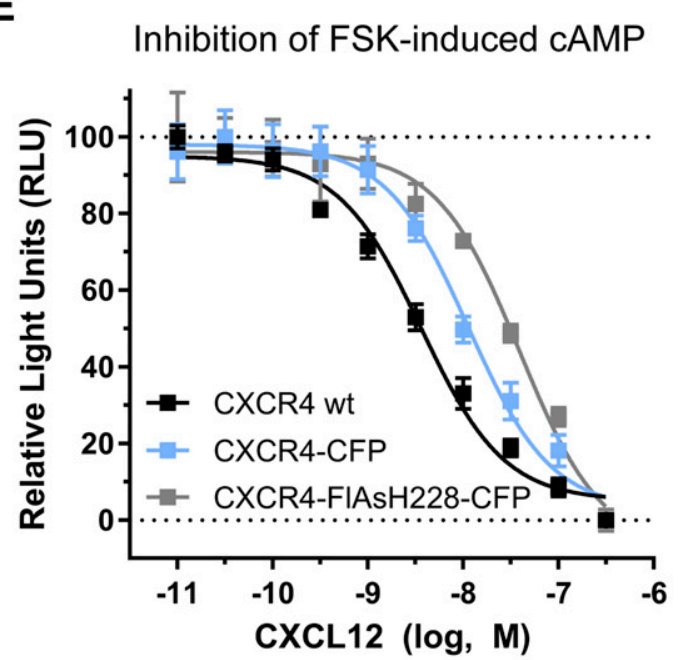

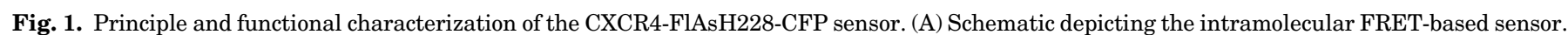

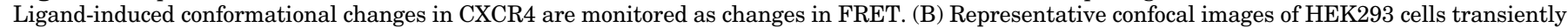

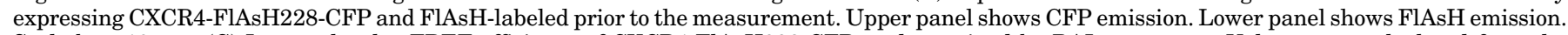

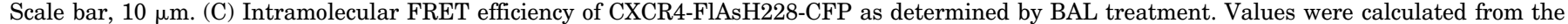

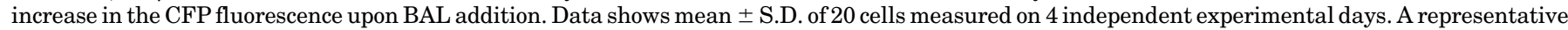

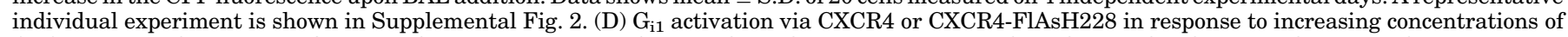

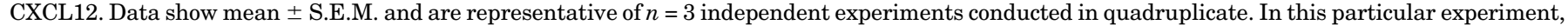

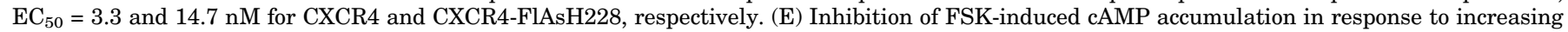

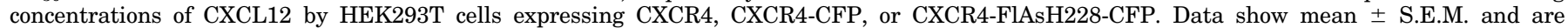

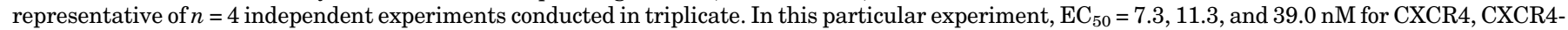

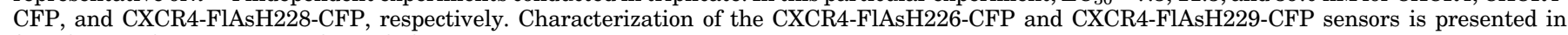
Supplemental Fig. 1. RLU, relative light unit.

targeting of one or a few cells without affecting the surrounding environment (Ainla et al., 2010, 2012; Wright et al., 2018). A more detailed description of the stimulation and wash-out steps is described in the Materials and Methods section.

Stimulation of cells expressing the CXCR4-FlAsH228-CFP sensor with CXCL12 induced a rapid increase in the FlAsH signal and a simultaneous decrease in the CFP signal, which led to an increase in the FRET ratio by $2 \%-5 \%(2.8 \% \pm 0.7 \%$; mean \pm S.D.) (Fig. 2, A and B; Supplemental Fig. 1G). Using this sensor, activation of CXCR4 occurred with a time constant $\tau=590$ (440-710) milliseconds (median and IQR) in response to CXCL12 (Fig. 2, C and D). Similar responses were observed when the CXCR4-FlAsH226-CFP and CXCR4-FlAsH229-CFP sensors were used to resolve the kinetics of receptor activation $[\tau=600$ (360-820) and $\tau=530$ (400-660) milliseconds, respectively; Supplemental Fig. 1D]. However, the amplitudes of the ligand-induced FRET signals with these two sensors were smaller than with CXCR4-FlAsH228-CFP $(2.1 \% \pm$ $0.6 \%$ for CXCR4-FlAsH226-CFP and $1.7 \% \pm 0.6 \%$ for CXCR4-FlAsH229-CFP; Supplemental Fig. 1, E-G). After stimulation, rapid superfusion of the cells with buffer removed the ligand, and the FRET signal returned to baseline, allowing the off-kinetics of the receptor to be determined. Deactivation of CXCR4 after CXCL12 stimulation occurred with $\tau=20.7$ (11.6-27.1) seconds (Fig. 2E). In summary, these sensors faithfully monitor the ligand-induced structural rearrangements 
A

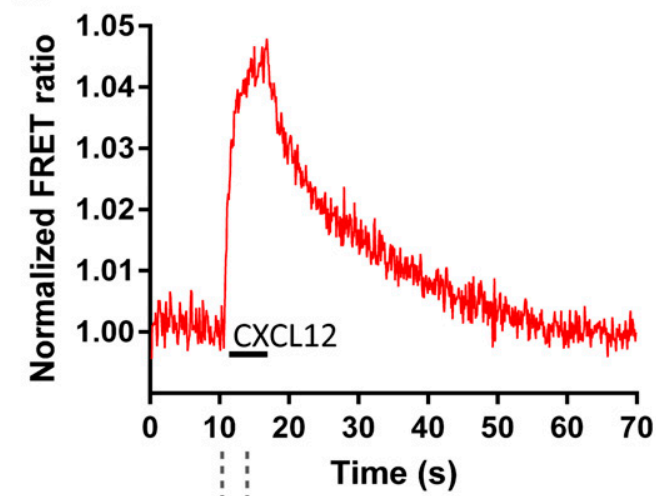

B

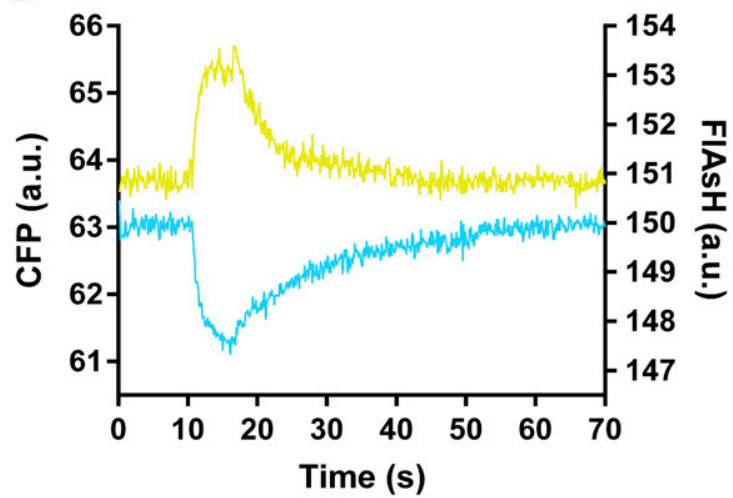

D

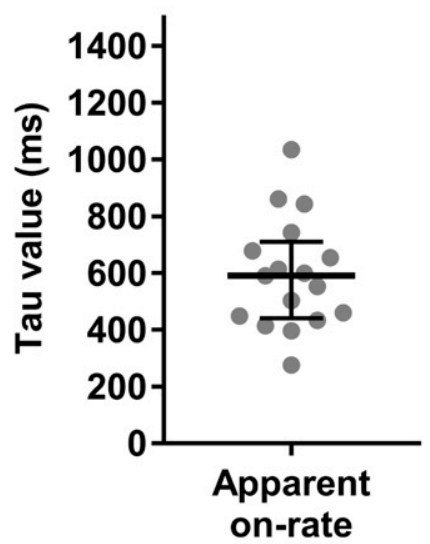

E

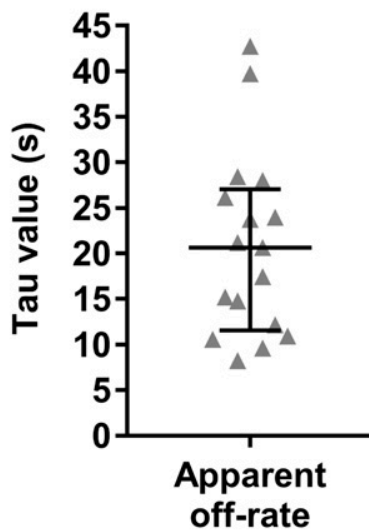

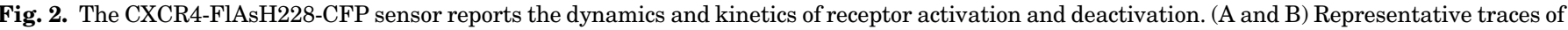

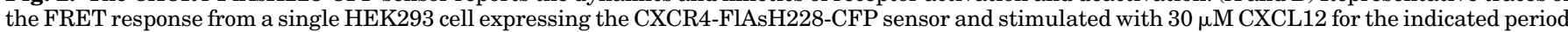

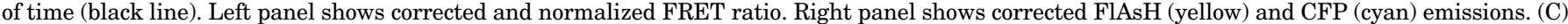

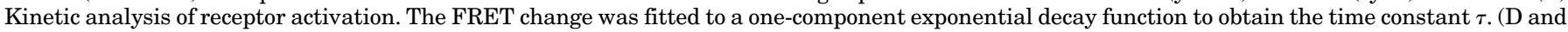

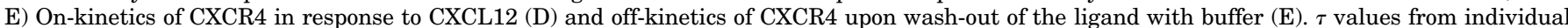

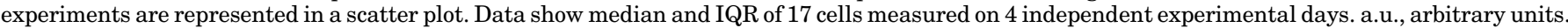

within the TM domain that reflect the activation of the receptor and have shown that the CXCL12-induced activation of CXCR4 is slower in comparison with other class A GPCRs and more similar to the activation of the class B PTHR.

CXCR4 and $G_{i}$ Proteins Remain within FRET Distance in the Absence of Agonist. Generally, activation of a GPCR results in the recruitment of G proteins to the agonistbound receptor. To determine the speed of coupling, we employed the constructs CXCR4-YFP and $\mathrm{G} \gamma_{2}$-CFP, which are coexpressed with the $\mathrm{G} \alpha_{\mathrm{i} 1}$ and $\mathrm{G} \beta_{1}$ subunits for proper stoichiometry and localization of the $G$ proteins to the plasma membrane (Fig. 3A). Surprisingly, and in contrast to what has been described for most GPCRs (Hein et al., 2005, 2006; Ferrandon et al., 2009; Hoffmann et al., 2012), stimulation of CXCR4 with CXCL12 $(30 \mu \mathrm{M})$ resulted in a decrease in the FRET signal with an amplitude of $3.3 \pm 1.0 \%$ (Fig. 3C). This rearrangement occurred at a speed of $\tau=960$ (870-980) milliseconds (Fig. 3E). To further investigate this effect, we examined the interaction of CXCR4-YFP with the G protein CFP-labeled at $\mathrm{G} \alpha_{\mathrm{i} 1}\left(\mathrm{G} \alpha_{\mathrm{i} 1}-\mathrm{CFP}\right)$ (Fig. 3B). Again, a decrease in the agonist-dependent FRET signal was detected upon receptor activation with an amplitude of $2.7 \% \pm 0.9 \%$ (Fig. 3D) and at a speed of $\tau=1030$ (750-1320) milliseconds (Fig. 3E).
Whether receptors are preassembled with $\mathrm{G}$ proteins or only associate upon agonist exposure is still a matter of debate and, so far, it seems to be dependent on the specific receptor/G protein pair (Hein and Bünemann, 2009; Andressen et al., 2018). To further study a potential interaction of CXCR4 with the $G_{i}$ protein in the absence of agonist, we performed acceptor photobleaching experiments in cells expressing CXCR4-YFP, $\mathrm{G} \gamma_{2}$-CFP, $\mathrm{G} \beta_{1}$, and $\mathrm{G} \alpha_{\mathrm{i} 1}$ (Fig. 4A). In parallel, the YFP-labeled $\alpha_{2 \mathrm{~A}} \mathrm{AR}$ was tested under the same conditions. CFP and YFP emission intensities were measured prior to and after photobleaching the YFP, and the changes detected in the $\mathrm{F}_{\mathrm{CFP}}$ were quantified. After photobleaching, no significant increase in $\mathrm{F}_{\mathrm{CFP}}$ was detected with the $\alpha_{2 \mathrm{~A}}$-AR-YFP $\left[\Delta \mathrm{F}_{\mathrm{CFP}}=0.4(-1.0\right.$ to 1.1) \%; median and IQR; Fig. 4, B and C], in agreement with published data (Hein et al., 2005). In contrast, a significant increase in $\mathrm{F}_{\mathrm{CFP}}$ was detected with CXCR4-YFP $\left[\Delta \mathrm{F}_{\mathrm{CFP}}=2.0\right.$ (1.0-3.1) \%; Fig. 4, B and D], indicating the existence of basal energy transfer prior to the photobleaching process. When such cells were treated with $10 \mu \mathrm{M}$ of the small molecule IT1t (antagonist), no significant change in $\mathrm{F}_{\mathrm{CFP}}$ upon YFP photobleaching was detected $\left[\Delta \mathrm{F}_{\mathrm{CFP}}=0.4(-0.4\right.$ to 1.2$) \%$; Fig. $4, \mathrm{~B}$ and E]. These findings suggest that although there is no specific interaction between $\alpha_{2 \mathrm{~A}}$-AR and the $\mathrm{G}_{\mathrm{i}}$ proteins in the 
A

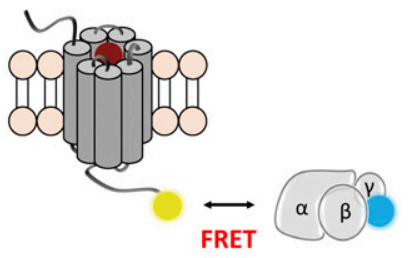

C

CXCR4-YFP + Gai1/Gß1/Gy2-CFP

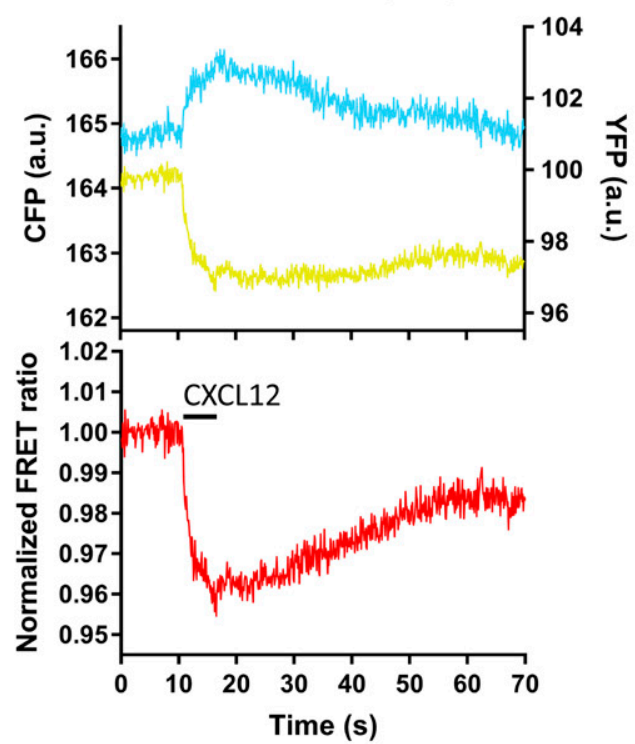

B

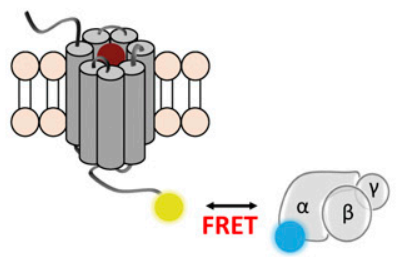

D

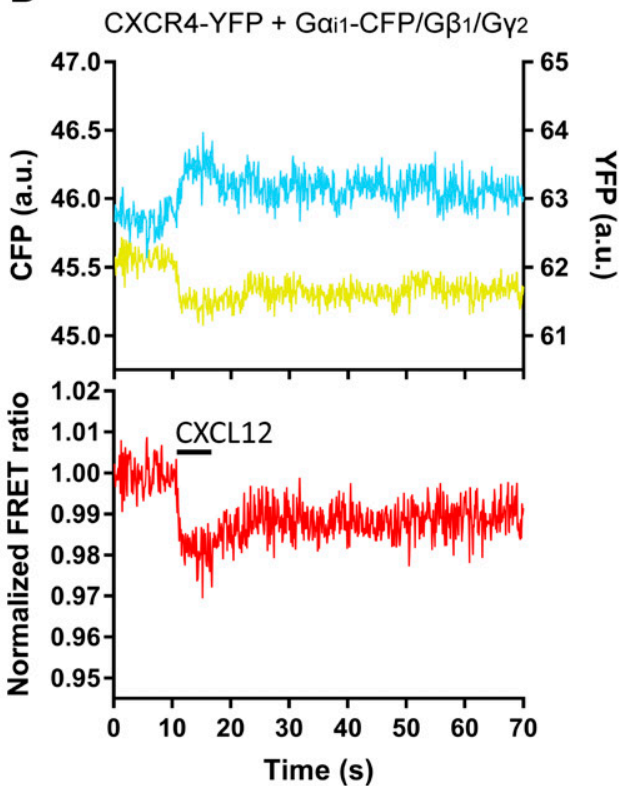

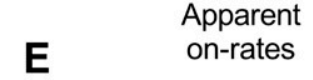

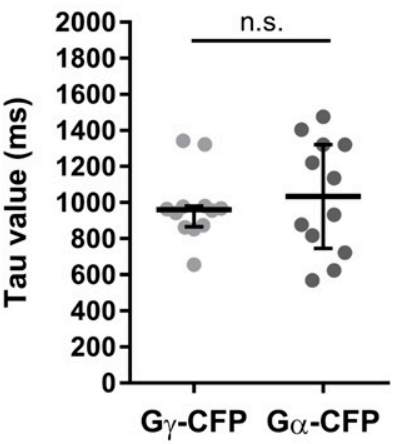

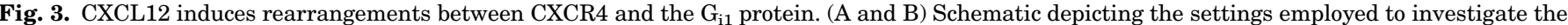

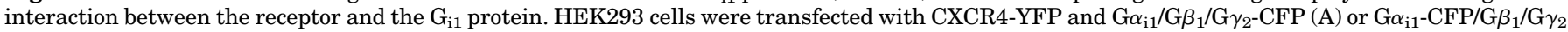

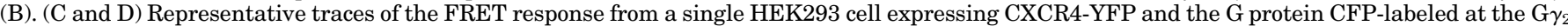

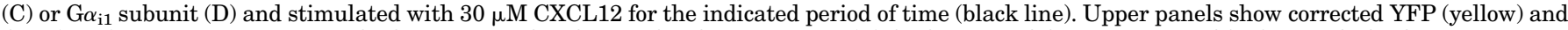

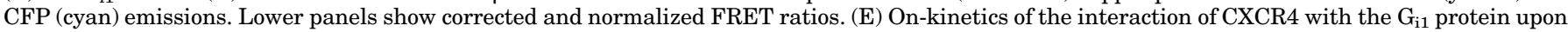

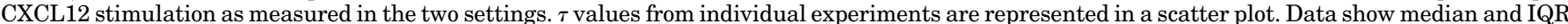

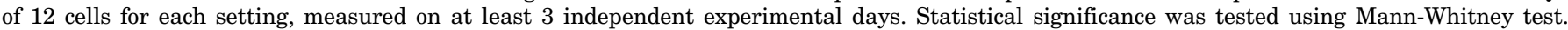
a.u.,arbitrary units; n.s., nonsignificant.

absence of agonist under these experimental conditions, CXCR4 resides within FRET distance of the $\mathrm{G}_{\mathrm{i}}$ protein, which might reflect a potential interaction between these two partners in the absence of agonist. Such behavior is consistent with other studies that suggest that CXCR4 exhibits some degree of basal receptor activity (Mishra et al., 2016; Mona et al., 2016).

CXCR4 Induces Prolonged $G_{i}$ Protein Activation in Response to CXCL12. To investigate the kinetics of $G_{i}$ protein activation, we used FRET-based sensors for $G_{i 1}, G_{i 2}$, and $\mathrm{G}_{\mathrm{i} 3}$ (van Unen et al., 2016). These sensors provide a realtime read-out for $\mathrm{G}$ protein activation by the loss of FRET between the $\mathrm{G} \gamma$ - and $\mathrm{G} \alpha$-labeled subunits in response to agonist stimulation of the receptor (Fig. 5A). HEK293 cells were cotransfected with CXCR4 or $\alpha_{2 \mathrm{~A}} \mathrm{AR}$ and one of the three $\mathrm{G}$ protein sensors. Then, single cells were stimulated with the appropriate ligand, either CXCL12 $(30 \mu \mathrm{M})$ or norepinephrine $(100 \mu \mathrm{M})$, using the BioPen. We detected activation of all three $\mathrm{G}$ protein subtypes via both receptors in response to their respective agonists, with no significant differences among the $\mathrm{G}$ protein subtypes. Upon stimulation, an immediate decrease in the FRET ratio was observed in every case (Fig. 5, B and C; Supplemental Fig. 3, A-D). Interestingly, the kinetic profiles of $\mathrm{G}$ protein activation via the two receptors were remarkably different. For CXCR4, G protein activation occurred with $\tau \approx 4$ seconds, whereas for $\alpha_{2 \mathrm{~A}} \mathrm{AR}, \mathrm{G}$ protein activation occurred with $\tau \approx 650$ milliseconds (Fig. 5D), which is almost an order of magnitude faster and in agreement with published data (Hein et al., 2005; Van Unen et al., 2016). After ligand exposure, cells were continuously washed with buffer to remove the ligands. In the case of the $\alpha_{2 \mathrm{~A}} \mathrm{AR}$, washing resulted in the FRET signal returning rapidly to baseline, which suggests that the $G$ proteins rapidly adopt once again the inactive conformation upon removal of the ligand. However, CXCL12 induced a prolonged $\mathrm{G}_{\mathrm{i}}$ activation via CXCR4, reflected by slower $G$ protein off-kinetics that could not be resolved in the time frame of the experiment (Fig. 5, B and C, lower panels; Supplemental Fig. 3, A-D). These observations suggest different $G$ protein activation by these two receptors, even though they both belong to class $\mathrm{A}$ GPCRs.

Further experiments were performed in a 96 -well plate FRET reader to test the effects of CXCL12-induced CXCR4 activation on $\mathrm{G}$ proteins. We observed a concentrationdependent activation of $\mathrm{G}_{\mathrm{i} 1}, \mathrm{G}_{\mathrm{i} 2}$, and $\mathrm{G}_{\mathrm{i} 3}$ in cells expressing CXCR4 (Fig. 5E, gray lines). The $\mathrm{EC}_{50}$ values obtained for CXCL12 were 6.7 [2.9-15.4] $\mathrm{nM}$ for $\mathrm{G}_{\mathrm{i} 1}$ activation, 9.9 [4.8-20.2] $\mathrm{nM}$ for $\mathrm{G}_{\mathrm{i} 2}$ activation, and 18.6 [8.4-40.9] $\mathrm{nM}$ for 
A

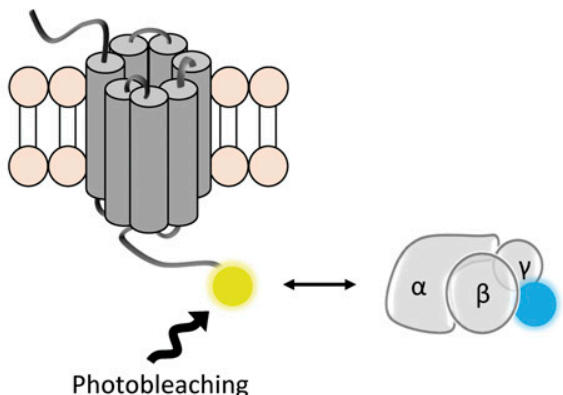

B

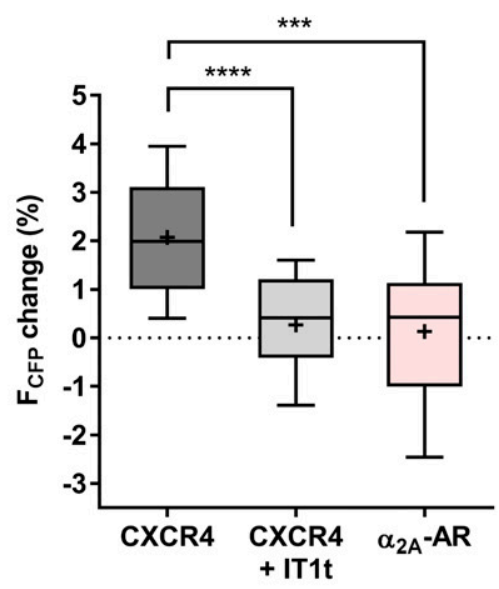

C

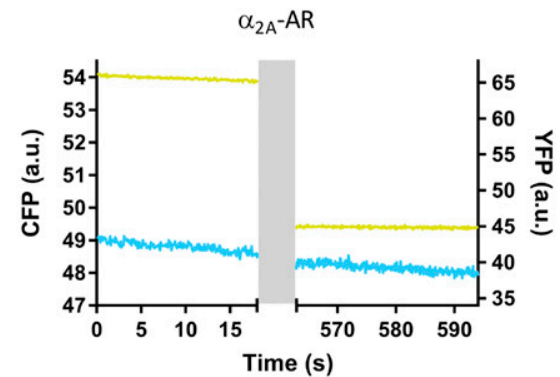

D

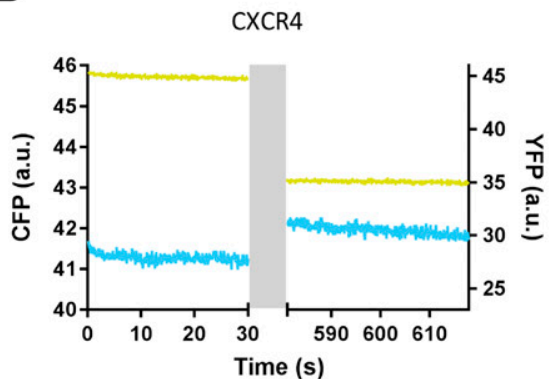

E

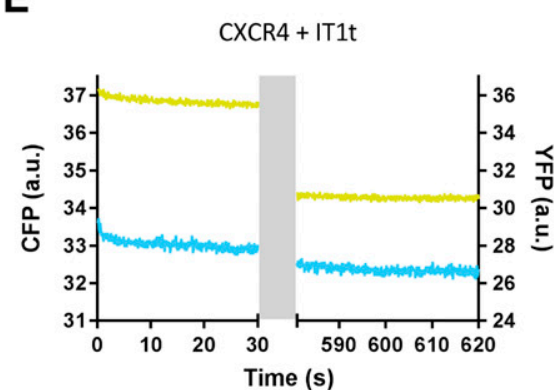

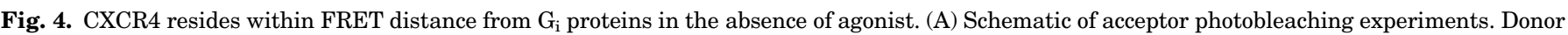

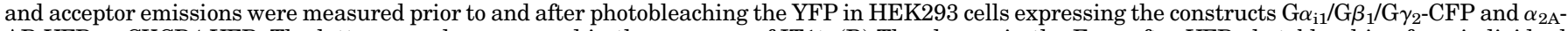

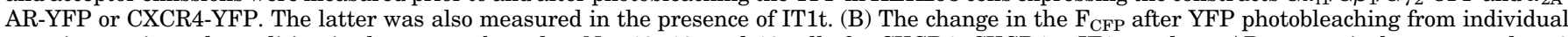

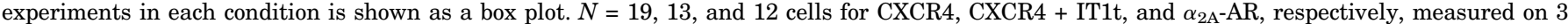

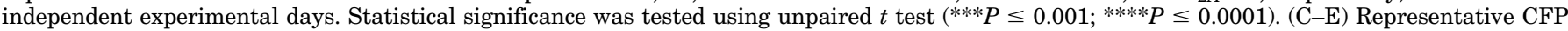
(cyan) and YFP (yellow) traces from individual experiments. The YFP photobleaching period is indicated in gray. a.u., arbitrary units.

$\mathrm{G}_{\mathrm{i} 3}$ activation. Therefore, the isoforms $\mathrm{G}_{\mathrm{i} 1}$ and $\mathrm{G}_{\mathrm{i} 2}$ were activated with significantly higher potency than $\mathrm{G}_{\mathrm{i} 3}$, which is in accordance with published data (Kleemann et al., 2008). The $\mathrm{EC}_{50}$ values obtained are also in good agreement with the potency of CXCL12 at CXCR4 described in other systems (Gupta et al., 2001; Rosenkilde et al., 2004; Kleemann et al., 2008; Levoye et al., 2009). No G protein activation was detected in cells expressing the $G$ protein sensors but not CXCR4 (Fig. 5E, black data points; controls for $\mathrm{G}_{\mathrm{i} 2}$ and $\mathrm{G}_{\mathrm{i} 3}$ not shown). Although the CXCL12/CXCR4 axis has also been shown to activate $\mathrm{G}_{\mathrm{q}}$ proteins in some contexts (Soede et al., 2001; Shi et al., 2007), we did not detect activation of $G_{q}$ using a FRET-based $\mathrm{G}_{\mathrm{q}}$ sensor (Fig. $5 \mathrm{E}$, brown data points; AdjoboHermans et al., 2011).

Since our data suggest a potential interaction between CXCR4 and $\mathrm{G}$ proteins in the absence of agonist, we next analyzed the effects of IT1t versus those of CXCL12 on the $\mathrm{G}_{\mathrm{i} 2}$ FRET sensor in CXCR4-expressing cells. FRET was analyzed under different conditions: buffer treatment, $100 \mu \mathrm{M}$ IT1t treatment, or $100 \mathrm{nM}$ CXCL12 treatment. We observed that IT1t caused a significantly higher FRET, and CXCL12 caused a significantly lower FRET compared with buffer (Fig. 5F). These data support the notion that CXCR4 activates G proteins in the absence of agonist or, in other words, that it exhibits some degree of basal receptor activity that can be blocked by IT1t, thus suggesting that this molecule would act as inverse agonist on CXCR4.
CXCR4 Homodimer Rearrangement Kinetically Precedes G Protein Activation. Despite the fact that GPCR monomers have been demonstrated to be functional units (Whorton et al., 2007), increasing evidence has emerged for a functional role of dimers and higher oligomeric structures (Milligan et al., 2019). Therefore, we next investigated the kinetics of the rearrangement that occurs between CXCR4 protomers upon binding of CXCL12. To do so, HEK293 cells were transfected with CXCR4-CFP and CXCR4-YFP and stimulated with the agonist CXCL12, again using the BioPen (Fig. 6A).

Upon stimulation of single cells with CXCL12 (30 $\mu \mathrm{M})$, a large increase in the FRET signal was detected with an amplitude of $7.5 \% \pm 2.8 \%$, which suggests an approximation of the two fluorophores in the active state of the receptor (Fig. 6B). Interestingly, this rearrangement occurred at a speed of $\tau=1660$ (1370-2010) milliseconds (Fig. 6C), which indicates that this movement is achieved faster than the activation of the $G$ proteins. Upon wash-out of the ligand with buffer, the signal returned to baseline, which allowed the determination of the off-kinetics of this process to be $\tau=$ 34.1 (21.3-36.1) seconds (Fig. 6D). Altogether, these data suggest that changes in CXCR4 homodimer occur slower than activation of a CXCR4 protomer. In contrast to our observations for CXCR4, several reports demonstrated that for the class $\mathrm{C}$ mGluR1, intersubunit rearrangements between protomers precedes intrasubunit rearrangements 
A
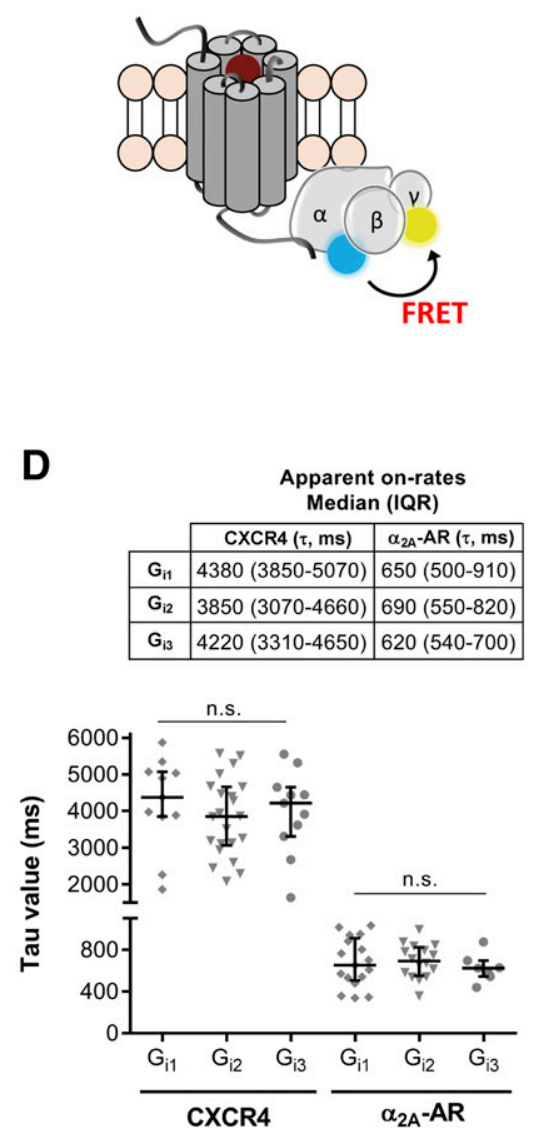

B

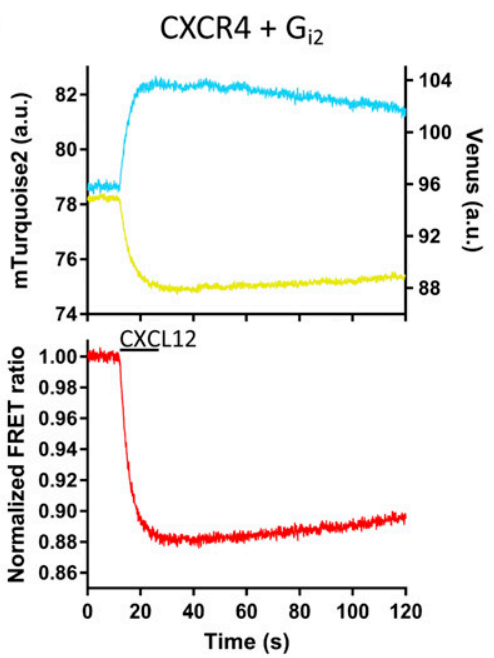

E

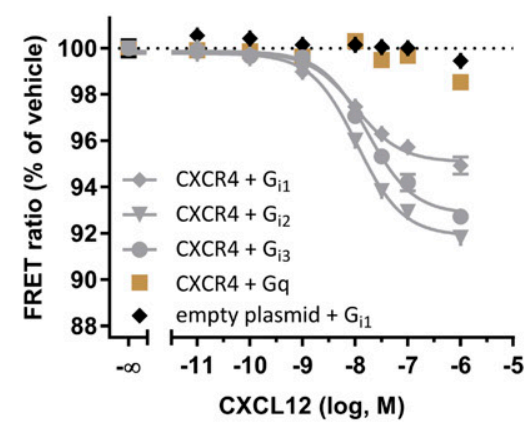

C
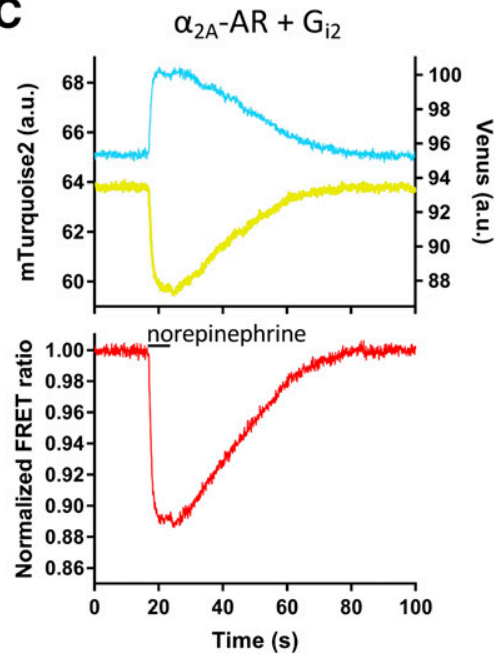

$\mathbf{F}$

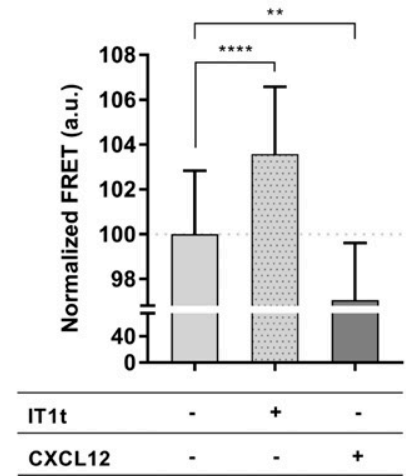

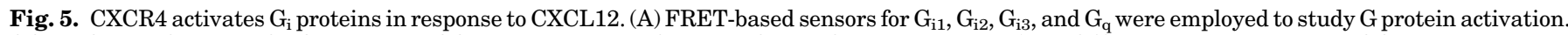

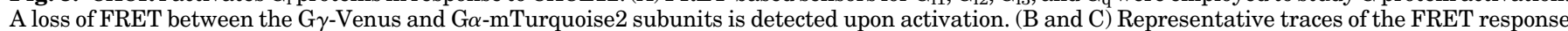

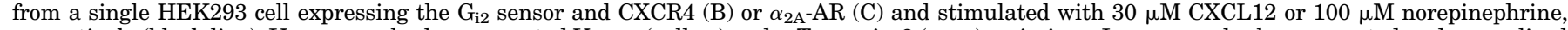

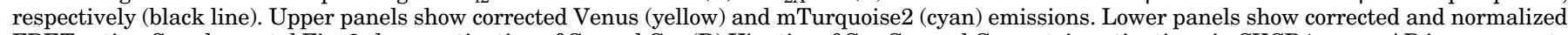

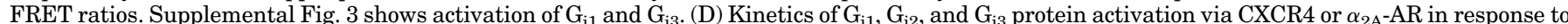

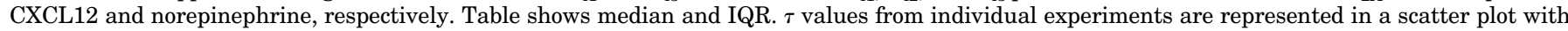

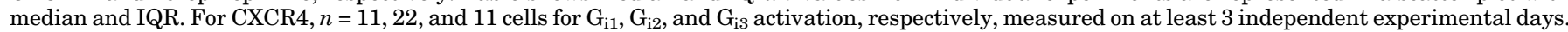

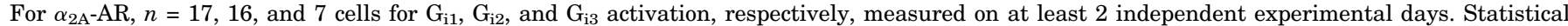

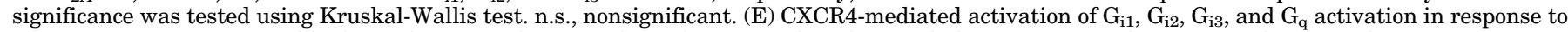

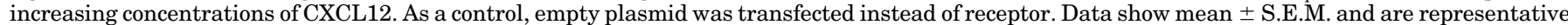

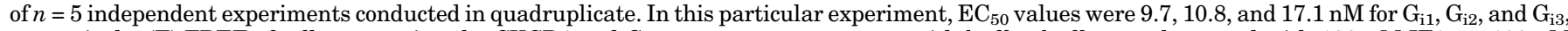

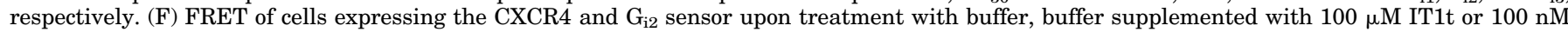

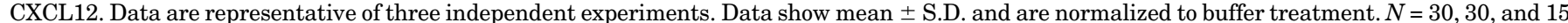

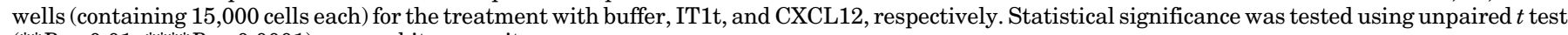
$(* * P \leq 0.01 ; * * * * P \leq 0.0001)$. a.u., arbitrary units.

(Hlavackova et al., 2012; Grushevskyi et al., 2019). This distinct behavior might be related to the different nature of the receptor dimers and might be a characteristic activation feature of class C GPCRs, for which dimerization is obligatory for function (Kniazeff et al., 2011; Zhang et al., 2014).

MIF Induces Distinct Structural Rearrangements in CXCR4 and Does Not Activate $G_{i}$ Proteins. MIF has been recently described to be able to bind and signal via CXCR4 as a partial agonist (Rajasekaran et al., 2016). Therefore, the settings that have been earlier established in this work to investigate the CXCL12-induced activation of CXCR4 were employed to investigate each step of the transduction pathway of this receptor in response to MIF. During the measurements, single cells expressing the construct(s) of interest were stimulated with $100 \mu \mathrm{M}$ MIF, followed by a short wash-out with buffer and subsequent stimulation with $30 \mu \mathrm{M}$ CXCL12.
First, receptor activation was investigated in cells transfected with the CXCR4-FlAsH228-CFP sensor and FlAsHlabeled prior to the measurement. In contrast to CXCL12, which produced an increase in the FRET signal, MIF binding to the sensor led to a decrease in the FRET ratio at a speed of $\tau$ $=270(250-440)$ milliseconds (Fig. 7, A and B). This suggests different conformational changes in CXCR4 by these two ligands. Washing of the cells with buffer after MIF stimulation rapidly returned the FRET signal to baseline, indicating that MIF can be easily removed from the receptor and suggesting a low ligand affinity. Subsequent stimulation with CXCL12 produced a response that was indistinguishable from the response observed when cells were directly stimulated with CXCL12, indicating that this response is not affected by the prior stimulation of the cells with MIF (Supplemental Fig. 4A). Second, the interaction of CXCR4 with the $G_{i}$ protein was 

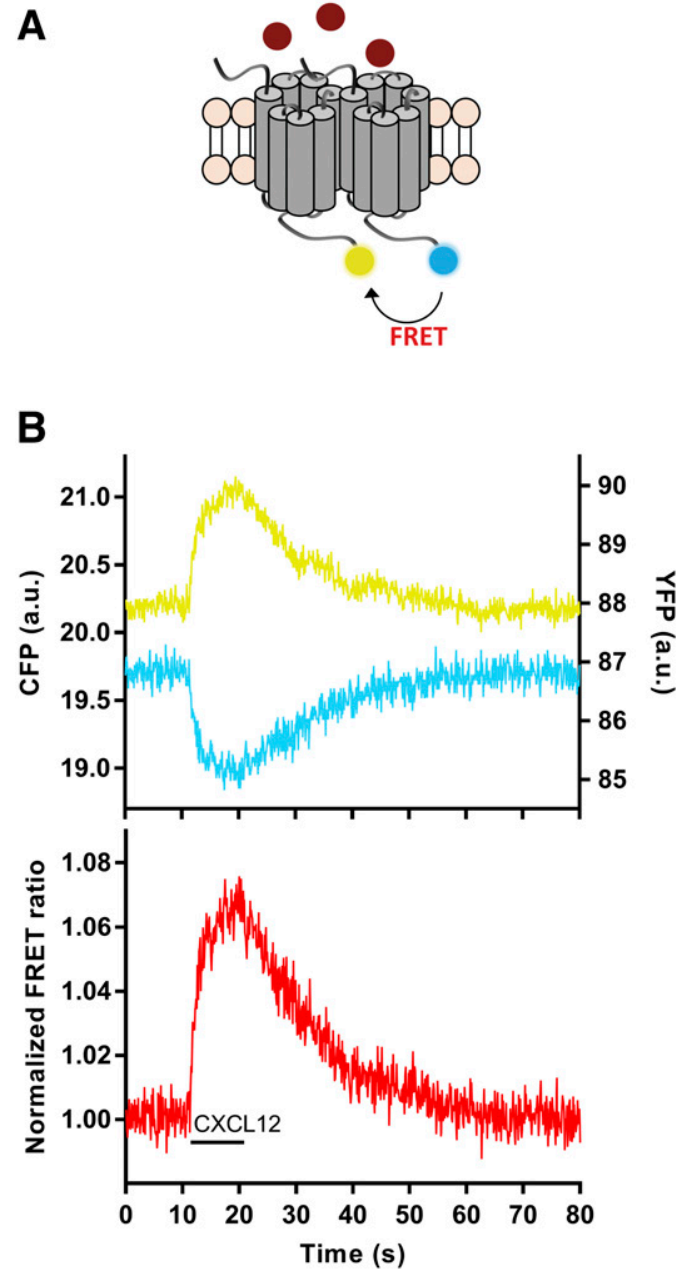
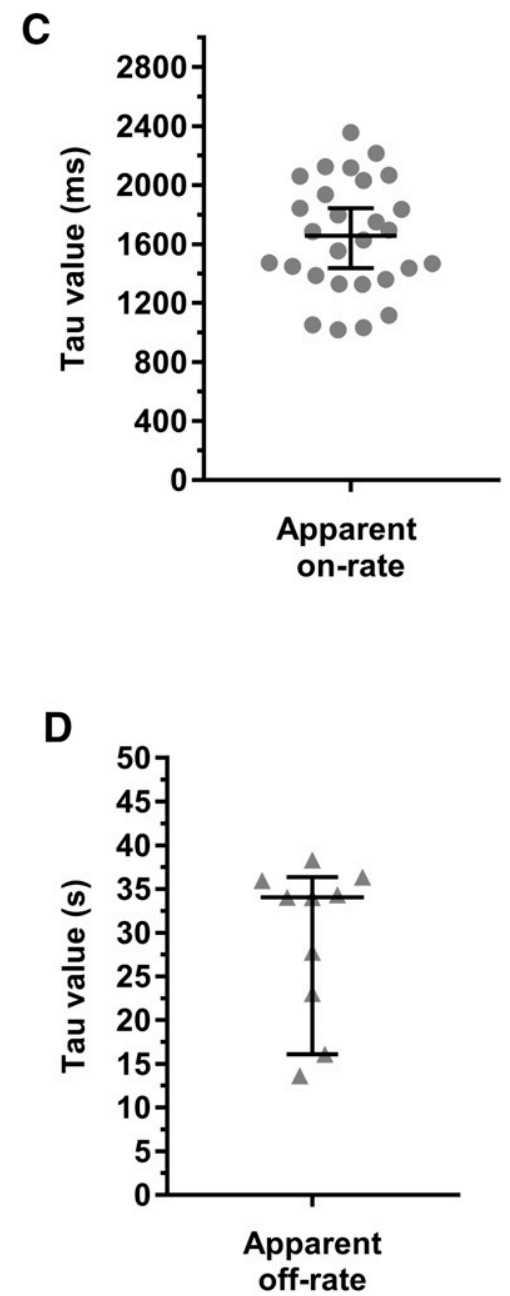

Fig. 6. CXCR4 homodimers undergo conformational changes in response to CXCL12. (A) The rearrangement between CXCR4 protomers was investigated in HEK293 cells cotransfected with CXCR4CFP and CXCR4-YFP, with the fluorophores fused to the $\mathrm{C}$ termini. (B) Representative traces of the FRET response from a single HEK293 cell expressing CXCR4-YFP and CXCR4-CFP and stimulated with $30 \mu \mathrm{M}$ CXCL12 (black line). Upper panel shows corrected YFP (yellow) and CFP (cyan) emissions. Lower panel shows corrected and normalized FRET ratio. (C and D) On-kinetics of the rearrangement between CXCR4 protomers in response to CXCL12 (C) and offkinetics upon wash-out of the ligand with buffer (D). $\tau$ alues from individual experiments are represented in a scatter plot with median and IQR. $N=28$ and 10 cells, respectively, measured on 4 independent experimental days. a.u., arbitrary units. examined in cells transfected with CXCR4-YFP and the G protein CFP-labeled at the $\mathrm{G} \gamma_{2}$ subunit. Upon stimulation with MIF, an increase in the FRET signal was observed with $\tau$ $=380(300-560)$ milliseconds (Fig. 7, C and D). Thus, again, MIF produced a response that is opposite to that of CXCL12, suggesting that the rearrangement of the $\mathrm{G}_{\mathrm{i}}$ protein with CXCR4 is different when the receptor is bound to MIF and CXCL12 and further supports the idea that the receptor adopts distinct conformations when bound to these two ligands. Upon washing of the cells with buffer, the FRET signal rapidly returned to baseline, and the cells could be subsequently stimulated with CXCL12, inducing a similar response to when cells are directly stimulated with this ligand (Supplemental Fig. 4B). Third, we investigated the movement between CXCR4 protomers upon MIF binding in cells transfected with CXCR4-CFP and CXCR4-YFP. We observed an MIF-induced decrease in the FRET signal that occurred at a speed of $\tau=870$ (580-930) milliseconds (Fig. 7, E and F). Again, the signal induced by MIF moved in the opposite direction, indicating once again different conformational changes in the receptor induced by these two ligands. The response induced by CXCL12 was also not affected by prior stimulation of the cells with MIF (Supplemental Fig. 4C). Fourth, cells transfected with CXCR4 and the $\mathrm{G}_{\mathrm{i} 2}$ sensor were employed to investigate receptor-mediated $G$ protein activation. Surprisingly, stimulation of the cells with MIF did not result in a change in FRET in the G protein sensor (Fig. 7G), indicating a lack of CXCR4-mediated G protein activation in response to this ligand. As a positive control, subsequent stimulation of the same cells with CXCL12 led to the activation of the $G$ protein. A summary of the kinetics of CXCR4 activation and signaling in response to MIF in comparison with CXCL12 is shown in Fig. 7H.

\section{Discussion}

The temporal resolution of individual biochemical steps that comprise a signaling cascade is important to understand cellular signaling. In this study, we report the kinetic and dynamic properties of early activation events in the CXCR4 transduction pathway in response to CXCL12 and MIF. Based on known movements of the TM domains that occur in GPCRs upon activation (Latorraca et al., 2017), we developed FRETbased sensors that are able to faithfully report the ligandinduced conformational changes in CXCR4. These constructs localize to the plasma membrane and preserve the ability to activate G proteins (Fig. 1), representing the first FRET sensors developed in the field of chemokine receptors.

The CXCR4 FRET sensors exhibited activation kinetics of $\tau \approx 600$ milliseconds in response to binding of the peptide agonist CXCL12 (Fig. 2). This is considerably slower than other class A receptors in response to small molecules, 
A

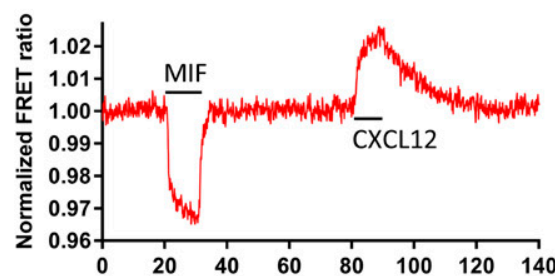

C

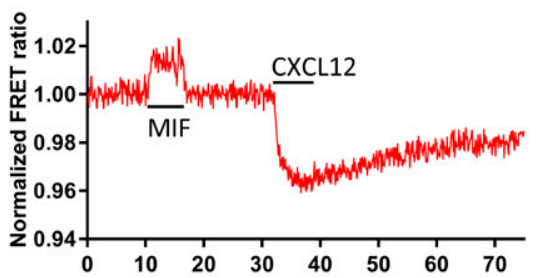

E

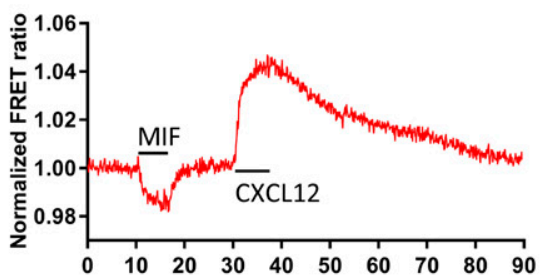

G

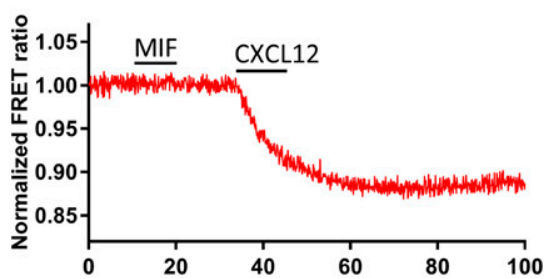

Receptor activation

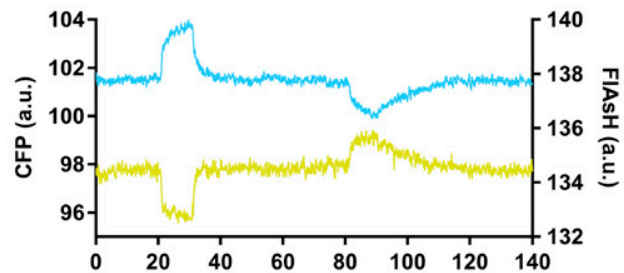

Receptor/G protein interaction

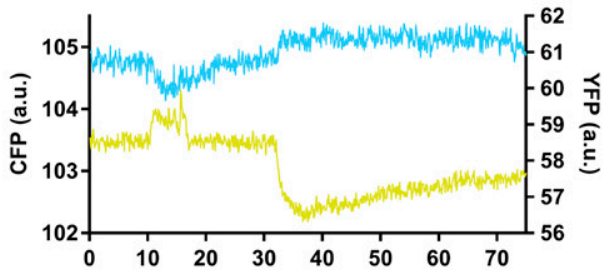

Dimer rearrangement

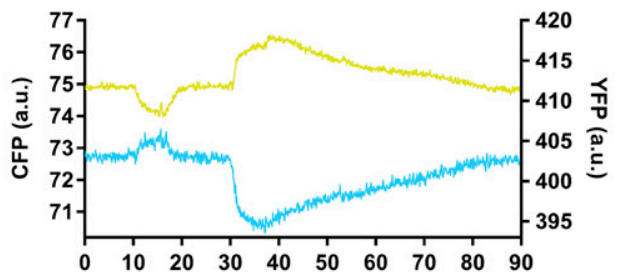

G protein activation

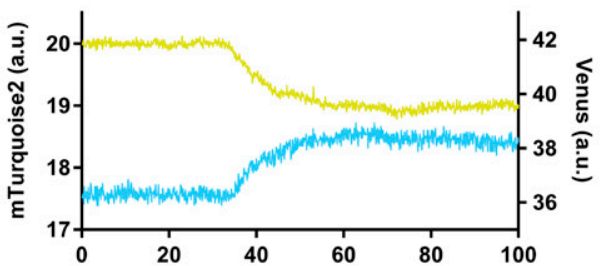

B

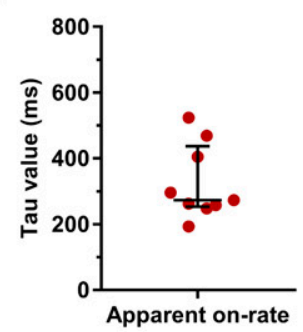

D

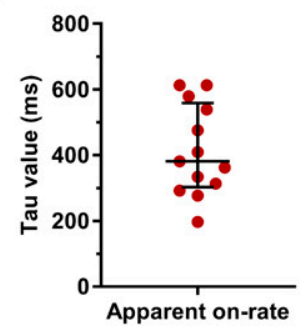

F

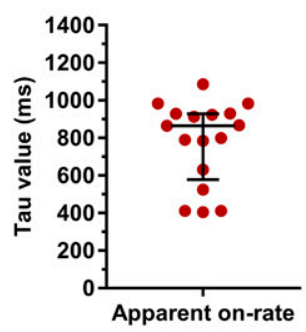

H Kinetic summary

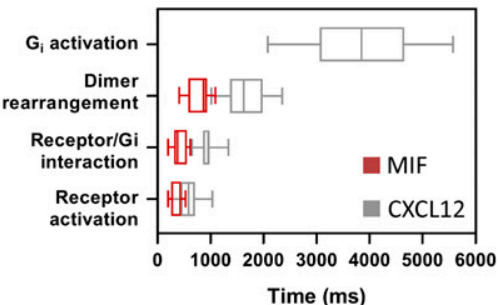

Fig. 7. MIF induces structural rearrangements in CXCR4 but does not lead to $\mathrm{G}_{\mathrm{i}}$ protein activation. (A, C, E, and G) Representative traces of the FRET response from a single HEK293 cell transiently expressing: CXCR4-FlAsH228-CFP sensor (A), CXCR4-YFP and G $\alpha_{\mathrm{ii}} / \mathrm{G} \beta_{1} / \mathrm{G} \gamma_{2}-\mathrm{CFP}(\mathrm{C})$, CXCR4-CFP and CXCR4-YFP (E) or CXCR4 and $\mathrm{G}_{\mathrm{i} 2}$ sensor $(\mathrm{G})$, which were stimulated with $100 \mu \mathrm{M}$ MIF and then followed by wash-out and then stimulation with $30 \mu \mathrm{M}$ CXCL12. Upper panels show corrected acceptor (yellow) and donor (cyan) emissions. Lower panels show corrected and normalized FRET ratios. (B, D, and F) On-kinetics of receptor activation $(n=9$ cells) (B), receptor/G protein interaction $(n=13$ cells) (D) and rearrangement between CXCR4 protomers $(n=17$ cells $)$ (F) in response to $100 \mu$ M MIF. $\tau$ values from individual experiments are represented in a scatter plot with median and IQR. Measurements were performed on at least 2 independent experimental days. (H) Comparison of CXCR4 on-kinetics in response to CXCL12 and MIF. Data from receptor activation belong to Figs. 2D and 7B. Data from receptor/G protein interaction belong to Figs. 3E (G $\gamma$-labeled) and 7D. Data from protomers rearrangement belong to Figs. $6 \mathrm{C}$ and $7 \mathrm{~F}$. Data from $\mathrm{G}$ protein activation belong to Fig. $5 \mathrm{D}\left(\mathrm{G}_{\mathrm{i} 2}\right.$ sensor). Data are shown as a box plot in which the whiskers represent maximum and minimum values. a.u., arbitrary units.

which exhibit activation time constants in the range of $2-50$ milliseconds (Vilardaga et al., 2003; Hoffmann et al., 2005; Rochais et al., 2007; Reiner et al., 2010; Ziegler et al., 2011; Grushevskyi et al., 2019). Interestingly, CXCL12-induced activation of CXCR4 occurred in the same time range as the activation kinetics determined for the class B PTHR in response to the peptide $\mathrm{PTH}(1-34)(\tau \approx 1$ second; Vilardaga et al., 2003). These differences in the activation kinetics might depend on intrinsic properties of the receptors, the type of ligand, and its binding mode. In this case, the 
binding of chemokines to their chemokine receptors proceeds via a complex mechanism that involves the formation of an extensive protein-protein interface with multiple recognition sites throughout the receptor (Wu et al., 2010; Kleist et al., 2016; Gustavsson et al., 2017). Likewise, PTH(1-34) was described to bind in two steps to PTHR (Castro et al., 2005).

The next signaling step we investigated led to the interesting observation of a decrease in the FRET signal between CXCR4-YFP and the CFP-labeled G protein upon CXCL12 stimulation (Fig. 3). Most receptors tested using this setting reported an increase in the FRET signal upon agonist stimulation, which is interpreted as G protein recruitment by the receptor (Hein et al., 2005, 2006). A recent study comparing the propensity of the two serotonin receptors $5-\mathrm{HT}_{4}$ and 5 $\mathrm{HT}_{7}$ to associate with $\mathrm{G}$ proteins showed that $5-\mathrm{HT}_{7}$ preassociates with $\mathrm{G}_{\mathrm{s}}$, whereas $5-\mathrm{HT}_{4}$ interacts with $\mathrm{G}_{\mathrm{s}}$ in an agonistdependent manner. Respectively, a decrease and increase in the FRET signals were detected (Andressen et al., 2018). Accordingly, our data might suggest that CXCL12 stimulation of CXCR4 does not lead to recruitment of the $G$ protein but rather to a rearrangement or dissociation of a preformed complex.

The spontaneous ligand-independent transition of GPCRs between inactive and active conformations is called basal or constitutive activity and is a common property of wt GPCRs but can also be a result of receptor mutations, which can cause a variety of diseases (Seifert and Wenzel-Seifert, 2002). Our results suggest a significant degree of basal activity for CXCR4. Photobleaching experiments in cells expressing CXCR4-YFP and CFP-labeled $\mathrm{G}_{\mathrm{i} 1}$ protein showed a ligandindependent energy transfer between these two proteins (Fig. 4). Although the nature of their interaction is unknown, these data suggest close proximity or potential interaction between CXCR4 and the $\mathrm{G}_{\mathrm{i}}$ protein prior to agonist stimulation. This hypothesis is further supported by the basal activation of $G_{i}$ proteins observed in the presence of CXCR4, which was abolished by addition of IT1t, hence indicating inverse agonist properties for this compound (Fig. 4; Fig. 5F). Considering that an estimated $85 \%$ of antagonists turn out to be inverse agonists when tested in contexts in which receptors exhibit constitutive activity (Kenakin, 2004), it is not surprising that IT1t, which has been considered a CXCR4 antagonist until now, exhibits inverse agonist properties in our assays. Although our findings indicate that CXCR4 exhibits constitutive activity (at least in regard to $\mathrm{G}$ protein signaling), stimulation of the cells with CXCL12 further activated G proteins, thus indicating that this activity was not saturated. The existence of basal CXCR4 activity is in agreement with observations in previous studies (Mishra et al., 2016; Mona et al., 2016). Since overexpression of CXCR4 has been widely reported for a large number of cancers and other pathologies (Müller et al., 2001; Balkwill, 2004; Darash-Yahana et al., 2004; Chatterjee et al., 2014b; Zhao et al., 2015), the degree of spontaneous activity might reach a significant level in these contexts and become therapeutically relevant. On the basis of our observations, the degree of basal activity of CXCR4 should be validated in such pathophysiological systems and in vivo. An in-depth understanding of the biology of CXCR4 in this respect should assist in the design of improved CXCR4targeting drugs.

When measuring $G$ protein activation, we made an intriging observation related to the G protein off-kinetics. Even after persistent wash-out of CXCL12 from the receptor, CXCR4mediated $G$ protein activation remained for a long time (Fig. 5B), whereas this was not the case for the norepinephrine $/ \alpha_{2 \mathrm{~A}}$-AR axis (Fig. $5 \mathrm{C}$ ) or other ligand/receptor pairs tested using these same G protein sensors (van Unen et al., 2016; Oehler et al., 2017; Grundmann et al., 2018). The nature of this observation is currently unknown to us, but several factors might play a role in this process. A possible explanation might be related to ligand residence time that might contribute to prolonged signaling (Hoffmann et al., 2015; Hothersall et al., 2016). Compared with norepinephrine and $\alpha_{2 \mathrm{~A}} \mathrm{AR}, \mathrm{CXCL} 12$ remains bound to CXCR4 for a significantly longer time period. This assumption is based on our observed slower CXCR4 off-kinetics upon CXCL12 stimulation and wash-out with buffer, which was roughly $\approx 21$ seconds (Fig. $2 \mathrm{E}$ ), hence approximately 10 times slower than the $\alpha_{2 \mathrm{~A}}$-AR sensor (Hein et al., 2005). However, this deactivation of the CXCR4 receptor was still much faster than the $G$ protein deactivation. Alternatively, the different receptors might induce distinct active conformations of the $G$ protein, which would display different lifetimes and GTPase activities (Furness et al., 2016). To mechanistically explain these differences in G protein offkinetics, further research is required.

Our study provides insights into the distinct mechanisms by which MIF and CXCL12 regulate the activity of CXCR4 and presents evidence for their different pharmacological properties. Our data indicate that binding of CXCL12 and MIF induces distinct structural rearrangements in CXCR4, which can be distinguished dynamically and kinetically at each step of the signaling cascade (Fig. 7). This suggests different binding modes of these two ligands to the same receptor, as proposed by other studies (Rajasekaran et al., 2016; Lacy et al., 2018). The extensive interaction interface between CXCL12 and CXCR4 involves interactions between the core of the ligand and the receptor $\mathrm{N}$ terminus as well as the ligand $\mathrm{N}$ terminus with the receptor TM cavity (Qin et al., 2015). In contrast, MIF binds to the N-terminal region of CXCR4 at different residues than CXCL12 and not within the TM cavity (Rajasekaran et al., 2016). Their different binding modes are also supported by the incomplete displacement of CXCL12 from CXCR4 by MIF (Supplemental Fig. 5; Bernhagen et al., 2007). Furthermore, and in line with our distinct FRET signals (MIF opposite to CXCL12) but in contrast to other studies, we did not detect $G_{i}$ protein activation via CXCR4 in response to MIF (Fig. 7G). Although our observations would suggest inverse agonist properties for MIF, functional data in other studies show that MIF acts as a CXCR4 allosteric partial agonist and mediates at least some of its functions via $G_{i}$ proteins (Bernhagen et al., 2007; Klasen et al., 2014; Rajasekaran et al., 2016). A possible explanation for these distinct observations could be the cellular context. Although MIF can bind to CXCR4 alone, its binding and function appear to be facilitated by the presence of the single-pass membranereceptor CD74 (cluster of differentiation 74), which together with CXCR4 forms a functional high-affinity heteromeric complex for MIF (Bernhagen et al., 2007; Schwartz et al., 2009; Klasen et al., 2014). HEK293 cells lack endogenous expression of CD74 (Schwartz et al., 2009), and, in our experiments, MIF was rapidly washed away from the receptor upon addition of buffer (Fig. 7, A, C, and E). The presence of CXCR4/CD74 complexes might be crucial in determining MIF signaling. For example, in platelets, which lack CD74, MIF 
A

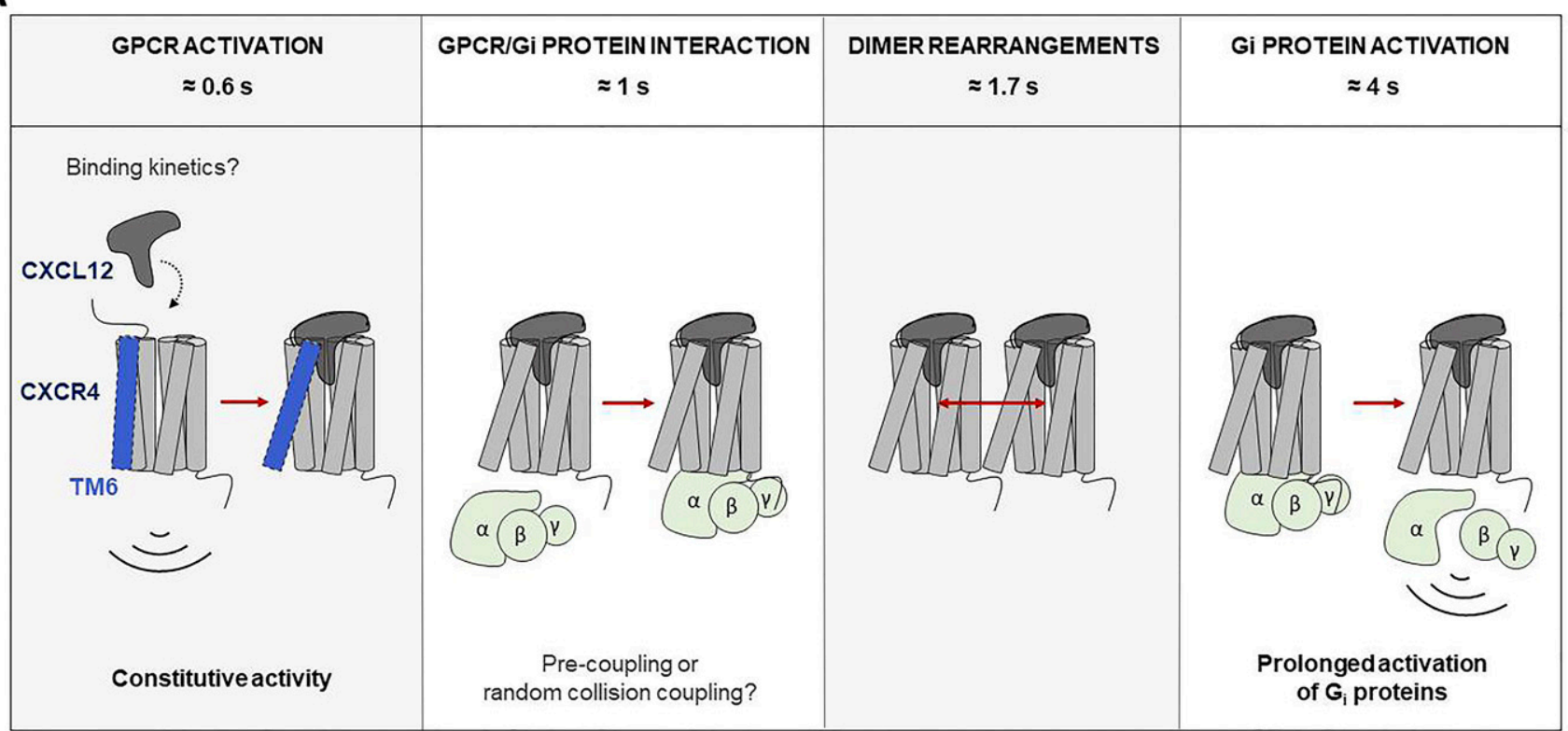

B

Model A

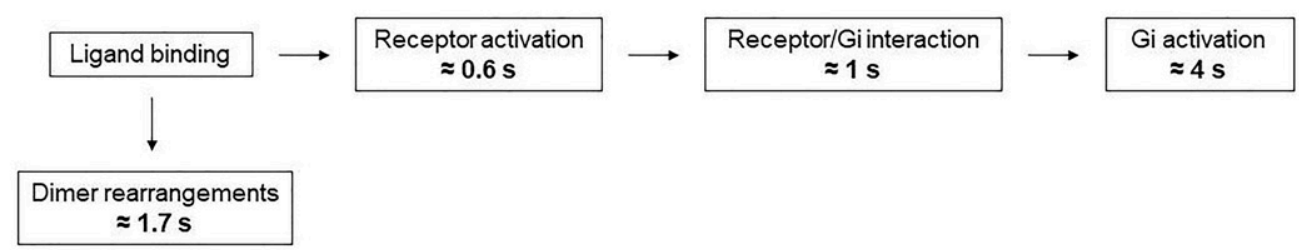

Model B

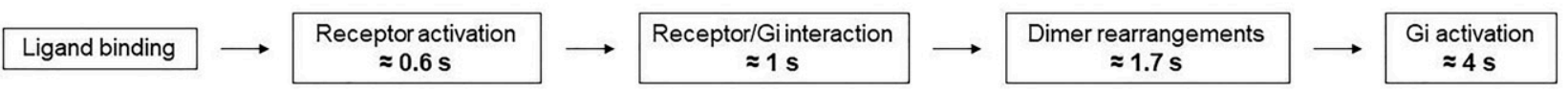

Fig. 8. Summary of the findings in this manuscript regarding the CXCL12/CXCR4 axis. The upper part of the figure shows the kinetics of each step of the signaling cascade investigated using FRET. The main findings regarding the CXCL12/CXCR4 axis are: 1) Activation kinetics of CXCR4 upon CXCL12 binding are slower than other class A GPCRs; 2) Rearrangements within dimers occur faster than activation of $G_{i}$ proteins; 3) This axis leads to a prolonged activation of $\mathrm{G}_{\mathrm{i}}$ proteins; and 4) CXCR4 exhibits some degree of constitutive activity. It is tempting to speculate that the rearrangement between protomers precedes $\mathrm{G}$ protein activation, which might suggest that conformational changes in CXCR4 homodimers, when present, play a possible role in the signaling activation course of this receptor as depicted in model B. However, we need to emphasize that mechanistic interpretation needs to be based on measuring microscopic rate constants, and hence, model A, in which the dimer rearrangement offers an alternative pathway, is also compatible with our dataset. a.u., arbitrary units.

could bind to CXCR4 but did not lead to extracellular signalregulated kinase phosphorylation, whereas MIF-induced extracellular signal-regulated kinase phosphorylation was detected in monocytes, which express both receptors (Chatterjee et al., 2014a).

In summary, we provide kinetic data from ensemble measurements for the early signaling steps of the human chemokine receptor CXCR4. Upon CXCL12 engagement, structural rearrangements within the TM domain $(\tau \approx 600$ milliseconds) are kinetically followed by rearrangements between CXCR4 and the G protein in the intracellular side that occur at a speed of $\tau \approx 1$ seconds. Furthermore, a structural rearrangement between CXCR4 protomers occurs with $\tau \approx 1.7$ seconds, whereas G protein activation by CXCR4 finally occurs with $\tau \approx 4$ seconds. These kinetic events are summarized in Fig. 8. It is tempting to speculate that the rearrangement between protomers precedes $G$ protein activation and to suggest that conformational changes in CXCR4 homodimers, when present, play a possible role in the signaling activation course of this receptor as depicted in model B. However, we need to emphasize that mechanistic interpretation needs to be based on measuring microscopic rate constants, and hence, model $\mathrm{A}$, in which dimer rearrangement offers an alternative pathway, is also compatible with our dataset.

\section{Acknowledgments}

We thank all colleagues from ONCORNET for helpful scientific discussions. 


\section{Authorship Contributions}

Participated in research design: Perpiñá-Viciano, Zarca, Kilpatrick,

Hoffmann.

Conducted experiments: Perpiñá-Viciano, Zarca, Caspar,

Kilpatrick.

Performed data analysis: Perpiñá-Viciano, Zarca, Caspar,

Kilpatrick.

Wrote or contributed to the writing of the manuscript: Perpiñá-

Viciano, Işbilir, Kilpatrick, Hill, Smit, Lohse, Hoffmann.

\section{References}

Adjobo-Hermans MJ, Goedhart J, van Weeren L, Nijmeijer S, Manders EM, Offermanns S, and Gadella TWJ Jr (2011) Real-time visualization of heterotrimeric G protein Gq activation in living cells. BMC Biol 9:32.

Adlere I, Caspar B, Arimont M, Dekkers S, Visser K, Stuijt J, de Graaf C, Stocks M, Kellam B, Briddon S, et al. (2019) Modulators of CXCR4 and CXCR7/ACKR3 function. Mol Pharmacol 96:737-752.

Ainla A, Jansson ET, Stepanyants N, Orwar O, and Jesorka A (2010) A microfluidic pipette for single-cell pharmacology. Anal Chem 82:4529-4536.

Ainla A, Jeffries GD, Brune R, Orwar O, and Jesorka A (2012) A multifunctional pipette. Lab Chip 12:1255-1261.

Alsayed Y, Ngo H, Runnels J, Leleu X, Singha UK, Pitsillides CM, Spencer JA Kimlinger T, Ghobrial JM, Jia X, et al. (2007) Mechanisms of regulation of CXCR4/ SDF-1 (CXCL12)-dependent migration and homing in multiple myeloma. Blood 109:2708-2717.

Altenbach C, Kusnetzow AK, Ernst OP, Hofmann KP, and Hubbell WL (2008) Highresolution distance mapping in rhodopsin reveals the pattern of helix movement due to activation. Proc Natl Acad Sci USA 105:7439-7444.

Andressen KW, Ulsund AH, Krobert KA, Lohse MJ, Bünemann M, and Levy FO (2018) Related GPCRs couple differently to $\mathrm{G}_{\mathrm{s}}$ : preassociation between $\mathrm{G}$ protein and $5-\mathrm{HT}_{7}$ serotonin receptor reveals movement of $\mathrm{G} \alpha$, upon receptor activation. FASEB J 32:1059-1069.

Balkwill F (2004) The significance of cancer cell expression of the chemokine receptor CXCR4. Semin Cancer Biol 14:171-179.

Bernhagen J, Krohn R, Lue H, Gregory JL, Zernecke A, Koenen RR, Dewor M, Georgiev I, Schober A, Leng L, et al. (2007) MIF is a noncognate ligand of CXC chemokine receptors in inflammatory and atherogenic cell recruitment. Nat Med 13:587-596.

Bobkov V, Arimont M, Zarca A, De Groof TWM, van der Woning B, de Haard H, and Smit MJ (2019) Antibodies targeting chemokine receptors CXCR4 and ACKR3. Mol Pharmacol 96:753-764.

Bünemann M, Frank M, and Lohse MJ (2003) Gi protein activation in intact cells involves subunit rearrangement rather than dissociation. Proc Natl Acad Sci USA 100:16077-16082.

Castro M, Nikolaev VO, Palm D, Lohse MJ, and Vilardaga JP (2005) Turn-on switch in parathyroid hormone receptor by a two-step parathyroid hormone binding mechanism. Proc Natl Acad Sci USA 102:16084-16089.

Chatterjee M, Borst O, Walker B, Fotinos A, Vogel S, Seizer P, Mack A, AlampourRajabi S, Rath D, Geisler T, et al. (2014a) Macrophage migration inhibitory factor limits activation-induced apoptosis of platelets via CXCR7-dependent Akt signaling. Circ Res 115:939-949.

Chatterjee S, Behnam Azad B, and Nimmagadda S (2014b) The intricate role of CXCR4 in cancer. Adv Cancer Res 124:31-82.

Chung KY (2013) Structural aspects of GPCR-G protein coupling. Toxicol Res 29 $149-155$

Darash-Yahana M, Pikarsky E, Abramovitch R, Zeira E, Pal B, Karplus R, Beider K Avniel S, Kasem S, Galun E, et al. (2004) Role of high expression levels of CXCR4 in tumor growth, vascularization, and metastasis. FASEB J 18:1240-1242.

Ferrandon S, Feinstein TN, Castro M, Wang B, Bouley R, Potts JT, Gardella TJ, and Vilardaga JP (2009) Sustained cyclic AMP production by parathyroid hormone receptor endocytosis. Nat Chem Biol 5:734-742.

Furness SGB, Liang YL, Nowell CJ, Halls ML, Wookey PJ, Dal Maso E, Inoue A Christopoulos A, Wootten D, and Sexton PM (2016) Ligand-dependent modulation of $\mathrm{G}$ protein conformation alters drug efficacy. Cell 167:739-749.e11.

Grundmann M, Merten N, Malfacini D, Inoue A, Preis P, Simon K, Rüttiger N, Ziegler N, Benkel T, Schmitt NK, et al. (2018) Lack of beta-arrestin signaling in the absence of active G proteins. Nat Commun 9:341.

Grushevskyi EO, Kukaj T, Schmauder R, Bock A, Zabel U, Schwabe T, Benndorf K and Lohse MJ (2019) Stepwise activation of a class C GPCR begins with millisecond dimer rearrangement. Proc Natl Acad Sci USA 116:10150-10155.

Guo F, Wang Y, Liu J, Mok SC, Xue F, and Zhang W (2016) CXCL12/CXCR4: a symbiotic bridge linking cancer cells and their stromal neighbors in oncogenic communication networks. Oncogene 35:816-826.

Gupta SK, Pillarisetti K, Thomas RA, and Aiyar N (2001) Pharmacological evidence for complex and multiple site interaction of CXCR4 with SDF-1alpha: implications for development of selective CXCR4 antagonists. Immunol Lett 78:29-34.

Gustavsson M, Wang L, van Gils N, Stephens BS, Zhang P, Schall TJ, Yang S, Abagyan R, Chance MR, Kufareva I, et al. (2017) Structural basis of ligand interaction with atypical chemokine receptor 3. Nat Commun 8:14135.

Hein P and Bünemann M (2009) Coupling mode of receptors and G proteins. Naunyn Schmiedebergs Arch Pharmacol 379:435-443.

Hein P, Frank M, Hoffmann C, Lohse MJ, and Bünemann M (2005) Dynamics of receptor/G protein coupling in living cells. $E M B O J \mathbf{2 4 : 4 1 0 6 - 4 1 1 4}$

Hein P, Rochais F, Hoffmann C, Dorsch S, Nikolaev VO, Engelhardt S, Berlot CH, Lohse MJ, and Bünemann M (2006) Gs activation is time-limiting in initiating receptor-mediated signaling. J Biol Chem 281:33345-33351.
Heuninck J, Perpiñá Viciano C, Işbilir A, Caspar B, Capoferri D, Briddon SJ, Durroux T, Hill S.J, Lohse MJ, Milligan G, et al. (2019) Context-dependent signaling of CXC chemokine receptor 4 and atypical chemokine receptor 3. Mol Pharmacol 96:778-793.

Hilger D, Masureel M, and Kobilka BK (2018) Structure and dynamics of GPCR signaling complexes. Nat Struct Mol Biol 25:4-12.

Hlavackova V, Goudet C, Kniazeff J, Zikova A, Maurel D, Vol C, Trojanova J, Prézeau L, Pin JP, and Blahos J (2005) Evidence for a single heptahelical domain being turned on upon activation of a dimeric GPCR. EMBO J 24:499-509.

Hlavackova V, Zabel U, Frankova D, Bätz J, Hoffmann C, Prezeau L, Pin JP, Blahos $J$, and Lohse MJ (2012) Sequential inter- and intrasubunit rearrangements during activation of dimeric metabotropic glutamate receptor 1. Sci Signal 5:ra59.

Hoffmann C, Castro M, Rinken A, Leurs R, Hill SJ, and Vischer HF (2015) Ligand residence time at G-protein-coupled receptors-why we should take our time to study it. Mol Pharmacol 88:552-560.

Hoffmann C, Gaietta G, Bünemann M, Adams SR, Oberdorff-Maass S, Behr B, Vilardaga JP, Tsien RY, Ellisman MH, and Lohse MJ (2005) A FlAsH-based FRET approach to determine $\mathrm{G}$ protein-coupled receptor activation in living cells. Nat Methods 2:171-176.

Hoffmann C, Gaietta G, Zürn A, Adams SR, Terrillon S, Ellisman MH, Tsien RY, and Lohse MJ (2010) Fluorescent labeling of tetracysteine-tagged proteins in intact cells. Nat Protoc 5:1666-1677.

Hoffmann C, Nuber S, Zabel U, Ziegler N, Winkler C, Hein P, Berlot CH, Bünemann $\mathrm{M}$, and Lohse MJ (2012) Comparison of the activation kinetics of the M3 acetylcholine receptor and a constitutively active mutant receptor in living cells. Mol Pharmacol 82:236-245.

Hothersall JD, Brown AJ, Dale I, and Rawlins P (2016) Can residence time offer a useful strategy to target agonist drugs for sustained GPCR responses? Drug Discov Today 21:90-96.

Hu J, Wang Y, Zhang X, Lloyd JR, Li JH, Karpiak J, Costanzi S, and Wess J (2010) Structural basis of G protein-coupled receptor-G protein interactions. Nat Chem Biol 6:541-548.

Jost CA, Reither G, Hoffmann C, and Schultz C (2008) Contribution of fluorophores to protein kinase C FRET probe performance. ChemBioChem 9:1379-1384.

Kenakin T (2004) Efficacy as a vector: the relative prevalence and paucity of inverse agonism. Mol Pharmacol 65:2-11.

Klasen C, Ohl K, Sternkopf M, Shachar I, Schmitz C, Heussen N, Hobeika E, LevitZerdoun E, Tenbrock K, Reth M, et al. (2014) MIF promotes B cell chemotaxis through the receptors CXCR4 and CD74 and ZAP-70 signaling. J Immunol 192: 5273-5284

Kleemann P, Papa D, Vigil-Cruz S, and Seifert R (2008) Functional reconstitution of the human chemokine receptor CXCR4 with G(i)/G (o)-proteins in Sf9 insect cells. Naunyn Schmiedebergs Arch Pharmacol 378:261-274.

Kleist AB, Getschman AE, Ziarek JJ, Nevins AM, Gauthier PA, Chevigné A, Szpakowska M, and Volkman BF (2016) New paradigms in chemokine receptor signa transduction: moving beyond the two-site model. Biochem Pharmacol 114:53-68.

Kniazeff J, Prézeau L, Rondard P, Pin JP, and Goudet C (2011) Dimers and beyond: the functional puzzles of class C GPCRs. Pharmacol Ther 130:9-25.

Kniazeff J, Saintot PP, Goudet C, Liu J, Charnet A, Guillon G, and Pin JP (2004) Locking the dimeric GABA(B) G-protein-coupled receptor in its active state $J$ Neurosci 24:370-377.

Lacy M, Kontos C, Brandhofer M, Hille K, Gröning S, Sinitski D, Bourilhon P, Rosenberg E, Krammer C, Thavayogarajah T, et al. (2018) Identification of an ArgLeu-Arg tripeptide that contributes to the binding interface between the cytokine MIF and the chemokine receptor CXCR4. Sci Rep 8:5171.

Latorraca NR, Venkatakrishnan AJ, and Dror RO (2017) GPCR dynamics: structures in motion. Chem Rev 117:139-155.

Levoye A, Balabanian K, Baleux F, Bachelerie F, and Lagane B (2009) CXCR7 heterodimerizes with CXCR4 and regulates CXCL12-mediated G protein signaling. Blood 113:6085-6093.

Lohse MJ, Maiellaro I, and Calebiro D (2014) Kinetics and mechanism of G proteincoupled receptor activation. Curr Opin Cell Biol 27:87-93.

Lohse MJ, Nuber S, and Hoffmann C (2012) Fluorescence/bioluminescence resonance energy transfer techniques to study G-protein-coupled receptor activation and signaling. Pharmacol Rev 64:299-336.

Messerer R, Kauk M, Volpato D, Alonso Cañizal MC, Klöckner J, Zabel U, Nuber S, Hoffmann C, and Holzgrabe U (2017) FRET studies of quinolone-based bitopic ligands and their structural analogues at the muscarinic $\mathrm{M}_{1}$ receptor. ACS Chem Biol 12:833-843.

Milligan G, Ward RJ, and Marsango S (2019) GPCR homo-oligomerization. Curr Opin Cell Biol 57:40-47.

Mishra RK, Shum AK, Platanias LC, Miller RJ, and Schiltz GE (2016) Discovery and characterization of novel small-molecule CXCR4 receptor agonists and antagonists. Sci Rep 6:30155.

Mona CE, Besserer-Offroy É, Cabana J, Leduc R, Lavigne P, Heveker N, Marsault É, and Escher E (2016) Design, synthesis, and biological evaluation of CXCR4 ligands. Org Biomol Chem 14:10298-10311.

Müller A, Homey B, Soto H, Ge N, Catron D, Buchanan ME, McClanahan T, Murphy E, Yuan W, Wagner SN, et al. (2001) Involvement of chemokine receptors in breast cancer metastasis. Nature 410:50-56.

Oehler B, Mohammadi M, Perpiñá Viciano C, Hackel D, Hoffmann C, Brack A and Rittner HL (2017) Peripheral interaction of resolvin D1 and E1 with opioid receptor antagonists for antinociception in inflammatory pain in rats. Front Mol Neurosci 10:242.

Qin L, Kufareva I, Holden LG, Wang C, Zheng Y, Zhao C, Fenalti G, Wu H, Han GW, Cherezov V, et al. (2015) Structural biology. Crystal structure of the chemokine receptor CXCR4 in complex with a viral chemokine. Science 347:1117-1122.

Rajasekaran D, Gröning S, Schmitz C, Zierow S, Drucker N, Bakou M, Kohl K, Mertens A, Lue H, Weber C, et al. (2016) Macrophage Migration Inhibitory FactorCXCR4 Receptor Interactions: evidence for partial allosteric agonism in comparison with CXCL12 chemokine. J Biol Chem 291:15881-15895. 
Reiner S, Ambrosio M, Hoffmann C, and Lohse MJ (2010) Differential signaling of the endogenous agonists at the beta2-adrenergic receptor. J Biol Chem 285 : 36188-36198.

Rochais F, Vilardaga JP, Nikolaev VO, Bünemann M, Lohse MJ, and Engelhardt S (2007) Real-time optical recording of beta1-adrenergic receptor activation reveals supersensitivity of the Arg389 variant to carvedilol. J Clin Invest 117: $229-235$.

Rosenkilde MM, Gerlach LO, Jakobsen JS, Skerlj RT, Bridger GJ, and Schwartz TW (2004) Molecular mechanism of AMD3100 antagonism in the CXCR4 receptor: transfer of binding site to the CXCR3 receptor. J Biol Chem 279:3033-3041.

Schwartz V, Lue H, Kraemer S, Korbiel J, Krohn R, Ohl K, Bucala R, Weber C, and Bernhagen J (2009) A functional heteromeric MIF receptor formed by CD74 and CXCR4. FEBS Lett 583:2749-2757.

Seifert R and Wenzel-Seifert K (2002) Constitutive activity of G-protein-coupled receptors: cause of disease and common property of wild-type receptors. Naunyn Schmiedebergs Arch Pharmacol 366:381-416.

Shi G, Partida-Sánchez S, Misra RS, Tighe M, Borchers MT, Lee JJ, Simon MI, and Lund FE (2007) Identification of an alternative Galphaq-dependent chemokine receptor signal transduction pathway in dendritic cells and granulocytes. $J$ Exp Med 204:2705-2718.

Soede RD, Zeelenberg IS, Wijnands YM, Kamp M, and Roos E (2001) Stromal cellderived factor-1-induced LFA-1 activation during in vivo migration of $\mathrm{T}$ cell hybridoma cells requires Gq/11, RhoA, and myosin, as well as $\mathrm{Gi}$ and Cdc42. $J$ Immunol 166:4293-4301.

Stoddart LA, Johnstone EKM, Wheal AJ, Goulding J, Robers MB, Machleidt T, Wood $\mathrm{KV}$, Hill SJ, and Pfleger KDG (2015) Application of BRET to monitor ligand binding to GPCRs. Nat Methods 12:661-663.

Stumpf $\mathrm{AD}$ and Hoffmann C (2016) Optical probes based on G protein-coupled receptors - added work or added value? $\mathrm{Br} J$ Pharmacol 173:255-266.

Tsibris AM and Kuritzkes DR (2007) Chemokine antagonists as therapeutics: focus on HIV-1. Annu Rev Med 58:445-459.

van Unen J, Stumpf AD, Schmid B, Reinhard NR, Hordijk PL, Hoffmann C, Gadella TWJ Jr., and Goedhart J (2016) A new generation of FRET sensors for robust measurement of $\mathrm{G}_{\alpha_{11}}, \mathrm{G}_{\mathrm{i} 2}$ and $\mathrm{G} \alpha_{\mathrm{i} 3}$ activation kinetics in single cells. PLoS One 11:e0146789.

Vilardaga JP, Bünemann M, Krasel C, Castro M, and Lohse MJ (2003) Measurement of the millisecond activation switch of $\mathrm{G}$ protein-coupled receptors in living cells. Nat Biotechnol 21:807-812.
Vilardaga JP, Nikolaev VO, Lorenz K, Ferrandon S, Zhuang Z, and Lohse MJ (2008) Conformational cross-talk between $\alpha_{2 A}$-adrenergic and $\mu$-opioid receptors controls cell signaling. Nat Chem Biol 4:126-131.

Vilardaga JP, Steinmeyer R, Harms GS, and Lohse MJ (2005) Molecular basis of inverse agonism in a G protein-coupled receptor. Nat Chem Biol 1:25-28.

Watts AO, van Lipzig MM, Jaeger WC, Seeber RM, van Zwam M, Vinet J, van der Lee MM, Siderius M, Zaman GJ, Boddeke HW, et al. (2013) Identification and profiling of CXCR3-CXCR4 chemokine receptor heteromer complexes. $\mathrm{Br}$ $J$ Pharmacol 168:1662-1674.

Whorton MR, Bokoch MP, Rasmussen SG, Huang B, Zare RN, Kobilka B, and Sunahara RK (2007) A monomeric G protein-coupled receptor isolated in a high-density lipoprotein particle efficiently activates its G protein. Proc Natl Acad Sci USA 104:7682-7687.

Wright SC, Alonso Cañizal MC, Benkel T, Simon K, Le Gouill C, Matricon P, Namkung Y, Lukasheva V, König GM, Laporte SA, et al. (2018) FZD5 is a Gaqcoupled receptor that exhibits the functional hallmarks of prototypical GPCRs. Sci Signal 11:eaar5536.

Wu B, Chien EY, Mol CD, Fenalti G, Liu W, Katritch V, Abagyan R, Brooun A, Wells P, Bi FC, et al. (2010) Structures of the CXCR4 chemokine GPCR with smallmolecule and cyclic peptide antagonists. Science 330:1066-1071.

Yang S, Edman LC, Sánchez-Alcañiz JA, Fritz N, Bonilla S, Hecht J, Uhlén P, Pleasure SJ, Villaescusa JC, Marín O, et al. (2013) Cxcl12/Cxcr4 signaling controls the migration and process orientation of A9-A10 dopaminergic neurons. Development 140:4554-4564.

Zhang XC, Liu J, and Jiang D (2014) Why is dimerization essential for class-C GPCR function? New insights from mGluR1 crystal structure analysis. Protein Cell 5:492-495. Zhao H, Guo L, Zhao H, Zhao J, Weng H, and Zhao B (2015) CXCR4 over-expression and survival in cancer: a system review and meta-analysis. Oncotarget 6:5022-5040.

Ziegler N, Bätz J, Zabel U, Lohse MJ, and Hoffmann C (2011) FRET-based sensors for the human M1-, M3-, and M5-acetylcholine receptors. Bioorg Med Chem 19: $1048-1054$

Address correspondence to: Dr. Carsten Hoffmann, Institute of Molecular Cell Biology, Center for Molecular Biomedicine (CMB), University Hospital Jena, University of Jena, Hans-Knöll-Str. 2, D-07745, Jena, Germany. E-mail: carsten.hoffmann@med.uni-jena.de 